\title{
Watch Your Language! The Kansas Law Review Survey of Official-English and English-Only Laws and Policies
}

\author{
Josh Hill, Devin Ross \& Brad Serafine* \\ Introduction by Richard E. Levy ${ }^{* *}$
}

\section{INTRODUCTION}

In recent years, immigration has become an increasingly controversial political issue and the "Official-English" movement has gathered steam. Many state and local governments have enacted Official-English laws or constitutional amendments, employers have promulgated English-only workplace policies, and the treatment of nonnative English speakers in the schools, the courts, and other aspects of public life has come under increasing public scrutiny. Such initiatives have led to an increasing number of legal challenges and an increasing number of judicial decisions addressing the implications of OfficialEnglish and English-only laws and policies. ${ }^{1}$ The student authors of this survey article therefore perform an important and useful service by reporting and describing Official-English and English-only laws and policies of various kinds, and gathering, organizing, and analyzing decisions that address these laws and policies in a variety of settings and under a variety of legal theories.

We may think of these developments as recent phenomena fueled by modern conditions, but language issues are as old as the United States itself. $^{2}$ Even before the Revolutionary War, for example, Benjamin

* J.D. candidates 2009, University of Kansas School of Law.

** J.B. Smith Distinguished Professor of Constitutional Law, University of Kansas School of Law. I would like to thank Justin Hendrix, Josh Hill, Devin Ross, and Brad Serafine for the opportunity to work with them on this project and to write this introduction.

1. Official-English and English-only policies often overlap, but they are not identical concepts. An Official-English policy concerns the status of English as the official language of public documents and discourse, but making English the official language does not necessarily imply that other languages cannot also be used. Conversely, while English-only policies prohibit the use of languages other than English, they may be adopted for reasons other than the "official" status of English and by private entities that have no authority to determine an official language.

2. See Dennis Baron, The English-Only Question: An Official Language for AMERICANS? 42 (1990) (discussing the post-Revolutionary War debate over the "official language" 
Franklin complained in a famous letter regarding German immigrants in Pennsylvania that "[f]ew of their children in the Country learn English" and that "legal Writings in their own Language ... are allowed good in our Courts." 3 In 1780, John Adams proposed the establishment of a national language academy, which would have effectively created an official English for the United States, but the proposal garnered little support and died in Congress. ${ }^{4}$ This failure is generally understood as a reflection of the then popular view that a national language academy would be "monarchist" in character and "inconsistent with principles of individual liberty." 5 Thus, even at the founding, there was tension between "a tolerant, expansive view of liberty that includes recognition and respect for the cultural differences of Americans" and "a demand for uniformity and assimilation to some vision of American identity, assumed to be homogeneous." ${ }^{\prime 6}$

Efforts to make English the official language of the United States or to discourage immigrants from continuing to use their native tongue have appeared periodically throughout our history, typically coinciding with significant waves of immigration and anti-immigration sentiment. ${ }^{7}$ One well-known example arose around the time of World War I, when a wave of anti-German sentiment resulted in many state laws prohibiting the teaching of foreign languages. In Meyer $v$. Nebraska ${ }^{8}$ the Supreme Court held that a law banning the teaching of a language other than English before the eighth grade improperly interfered with the liberty of

of the United States).

3. Letter from Benjamin Franklin to Peter Collinson (May 9, 1753), in LANGUAGE LOYALties: A SOURCE BOOK ON THE OfFiCiAL ENGLiSh CONTROVERSY 18-19 (James Crawford ed., 1992).

4. Juan F. Perea, Demography and Distrust: An Essay on American Languages, Cultural Pluralism, and Official English, 77 MiNN. L. REV. 269, 295 (1992).

5. Id. at 297.

6. Id. at $275-76$.

7. For a comprehensive historical discussion of the Official-English issue and English-only laws, see BARON, supra note 2, and Perea, supra note 4. See also Donna F. Coltharp, Comment, Speaking the Language of Exclusion: How Equal Protection and Fundamental Rights Analyses Permit Language Discrimination, 28 ST. MARY's L.J. 149, 158-64 (1996) (summarizing history); Carol Schmid, Comment, Language Rights and the Legal Status of English-Only Laws in the Public and Private Sector, 20 N.C. CENT. L.J. 65, 67-72 (1992) (same); Cecilia Wong, Note, Language is Speech: The Illegitimacy of Official English After Yniguez v. Arizonians for Official English, 30 U.C. DAVIS L. REV. 277, 280-85 (1996) (same). Ironically, efforts to compel linguistic and cultural assimilation have not been limited to immigrants; forcing Native Americans to abandon their mother tongue and learn English was a prominent feature of United States Indian policy for some time. See generally Allison M. Dussias, Waging War with Words: Native Americans' Continuing Struggle Against the Suppression of Their Languages, 60 Oніо ST. L.J. 901, 905-28 (1999). See also Allison M. Dussias, Indigenous Languages Under Siege: The Native American Experience, 3 INTERCULTURAL HUM. RTS. L. REV. 5, 8-18 (2008).

8. 262 U.S. 390 (1923). 
parents to determine the education of their children. ${ }^{9}$ The principal rationale of the case was that the state lacked the authority to interfere with this liberty because there was no valid state police power justification for the law, insofar as teaching foreign language was not in any way harmful to children. ${ }^{10}$ In the course of its opinion, however, the Court also pronounced broadly that " $[\mathrm{t}]$ he protection of the Constitution extends to all, to those who speak other languages as well as to those born with English on the tongue." 11 Later, in the famous "footnote 4" of United States v. Carolene Products, the Court characterized Meyer and similar cases as involving discrimination against "particular... national ... minorities." 12

As this discussion suggests, current efforts to make English the official language of the United States and to adopt English-only laws and policies have much in common with their historical predecessors. Then, as now, the debate reflects a tension between demands for assimilation and respect for cultural differences. Then, as now, proponents of Official-English laws emphasized the ways in which a common language unifies the population and defines the political community. ${ }^{13}$ Then, as now, language was central to individual identity and social belonging. Then, as now, the issues were tinged with racial, ethnic, and religious prejudices. Thus, it is hardly surprising that then, as now, the issue was one that evoked strong, emotional responses.

Although located at the geographic center of the country, Kansas is not immune from these forces and has a fascinating history of linguistic minorities. ${ }^{14}$ Many German speaking immigrants settled in Kansas during the nineteenth century, establishing communities in which

\footnotetext{
9. Id. at $399-400$.

10. Id. at 400 .

11. Id. at 401 .

12. United States v. Carolene Prods. Co., 304 U.S. 144, 152 n.4 (1938) (citing Bartels v. Iowa, 262 U.S. 404 (1923) (companion case to Meyer) and Farrington v. Tokushige, 273 U.S. 284 (1927) (following Meyer)).

13. In Meyer, for example, the Court described the purposes of the law as follows:

It is said the purpose of the legislation was to promote civic development by inhibiting training and education of the immature in foreign tongues and ideals before they could learn English and acquire American ideals, and "that the English language should be and become the mother tongue of all children reared in this state." It is also affirmed that the foreign born population is very large, that certain communities commonly use foreign words, follow foreign leaders, move in a foreign atmosphere, and that the children are thereby hindered from becoming citizens of the most useful type and the public safety is imperiled.

Meyer, 262 U.S. at 401.

14. See J. Neale Carman, Foreign-Language Units of Kansas: Historical Atlas and STATISTICS 1-3 (1962).
} 
German dialects were spoken - and continue to be spoken to this day. ${ }^{15}$ More recently, other immigrant populations in Kansas have grown, especially the Hispanic community, as reflected in the following data from the 2000 census:

\begin{tabular}{cc}
$\begin{array}{c}\text { Language Spoken at Home in Kansas for the } \\
\text { Population 5 Years and Over }\end{array}$ \\
\hline Language & Speakers \\
\hline Spanish & 137,245 \\
German & 16,820 \\
Vietnamese & 10,395 \\
French & 6535 \\
Chinese & 5435 \\
Korean & 3665 \\
Laotian & 3145 \\
Arabic & 2835 \\
Tagalog & 2235 \\
Russian & 1995 \\
\hline
\end{tabular}

While the Official-English movement and English-only laws are not new, what is new, perhaps, is the wide array of contexts in which these issues may arise and the variety of constitutional doctrines and federal statutes that may be implicated. In general terms, the cases focus on improper discrimination and/or interference with political liberties, although the issues may overlap and the specific legal questions raised by a given case vary depending on the particular context in which the case arises.

To bring order to the complex morass, the authors have divided the discussion into five parts. Part II considers the status of legislation and constitutional amendments to establish English as the "official" language of a state or of the United States, and discusses cases seeking to enforce or challenge such laws. Part III examines the distinctive issues raised at the intersection of Official-English or English-only laws and voting, including constitutional issues arising out of the right to vote and the

15. William D. Keel, Deitsch, Däätsch, Düütsch, and Dietsch: The Varieties of Kansas German Dialects after 150 Years of German Group Settlement in Kansas, in PreSERVING HeRITAGE: A FESTSCHRIFT FOR C. RICHARD BEAM (Joshua R. Brown and Leroy T. Hopkins, Jr. eds.), 2 YEARBOOK OF GERMAN-AMERICAN STUDIES 27-48 (Supp. 2006).

16. United States Census Bureau, Report: Language Spoken at Home for the POPULATION 5 YEARS AND OVER (Apr. 2004), available at http://www.census.gov/mp/www/ spectab/specialtab.html. 
Equal Protection Clause, as well as statutory issues under the Voting Rights Act. Part IV focuses on education, a field in which a contemporary policy debate over bilingual education rages and constitutional issues arise alongside interpretive questions under various federal statutes. Part V discusses language issues and jury service, a context in which issues of discrimination and participatory rights are further complicated by the distinctive problem of witness testimony that may be translated from another language. Finally, Part VI considers English-only policies in the workplace, which may give rise to claims under Title VII of the Civil Rights Act, 42 U.S.C. $\S$ 1981, the Equal Protection Clause, or the First Amendment.

The settings and specific legal issues discussed in the different parts of the survey vary widely, but the fundamental underlying questions are the same. What are the obligations of immigrants as members of the political community to learn English? What are the obligations of government to accommodate linguistic differences so as to permit nonEnglish speakers to participate in public life? To what extent does speaking a language other than English cause immigrant groups to remain separate from the political community at large and, conversely, to what extent is speaking in another language a protected political or personal liberty? How can we separate legitimate concerns about encouraging participation in the mainstream of American life from subtle and hidden forms of racial, ethnic, and religious discrimination? This survey makes clear that there are no easy answers to these perennial questions, as the courts no less than those in the political sphere continue to struggle with what it means to be an American.

\section{State AND Federal OfFicial-EngLish LANGUAGE StatuTES}

\section{A. Introduction and Background}

While the federal government has never officially declared English the official language, thirty states have now passed "Official-English" laws. ${ }^{17}$ Although the wording of these laws varies greatly from state to state, they can generally be divided into one of three categories. The first group is sometimes referred to as "obligatory" or "English-only" statutes. These statutes specify that English is to be the only language used for government documents, meetings, and all other official actions. ${ }^{18}$ Due to

17. English as Our Official Language, http://www.proenglish.org/issues/offeng/states.html (last visited Dec. 8, 2008).

18. See, e.g., ARIZ. CONST. art. XXVIII; AlASKa Stat. § 44.12 .320 (2007). 
their restrictive nature, these statutes have been subjected to significant litigation with First Amendment implications. The second group of statutes is an intermediary group, which includes statutes that are more than symbolic in nature, but do not go so far as to require that English be the only language of government. The last group is often referred to as "symbolic" Official-English statutes, which usually include a brief statement declaring English to be the state's official language, similar to the way a state may declare a state bird, fish, or song. ${ }^{19}$ These symbolic statutes are rarely the subject of litigation because they have few, if any, legal effects. This section will discuss a history of federal attempts to establish English as the official language as well as the litigation trends involving state Official-English statutes.

\section{B. Federal Official-English Legislation}

While over a third of Americans believe English to be the official language of the United States, the federal government has never formally recognized it as such. A modern movement to establish English as the official language began in 1981 when U.S. Senator Hayakawa presented an Official-English constitutional amendment to Congress. ${ }^{20}$ While the amendment was not ratified, his proposal spurred similar efforts in many state governments. $^{21}$ Almost every congressional legislative session since 1981 has seen a proposed Official-English amendment to the Constitution. ${ }^{22}$

In May 2006, the Senate approved two bills that, if adopted by the House and approved by the President, would have taken a large step toward establishing English as the official language of the United States. The first bill, known as the Inhofe Amendment, after Oklahoma Senator James Inhofe, was passed by a 64-34 vote. ${ }^{23}$ This amendment was added to the Comprehensive Immigration Reform Act and would have required the government to "preserve and enhance the role of English as the

19. See, e.g., ARK. Code AnN. § 1-4-117 (West 2004); InD. Code ANN. § 1-2-10-1 (West 2000); Ky. Rev. StAT. ANN. § 2.013 (West 2006); N.C. Gen. StAt. AnN. § 145-12 (West 2000).

20. Marla B. Somerstein, Comment, Official Language A, B, Cs: Why the Canadian Experience with Official Languages Does Not Support Arguments to Declare English the Official Language of the United States, 38 U. MiAmI INTER-AM. L. REV. 251, 260 (2006).

21. Adriana Resendez, The Spanish Predominant Language Ordinance: Is Spanish on the Way In and English on the Way Out?, 32 ST. MARY's L.J. 317, 330-31 (2001).

22. Somerstein, supra note 20, at 260 (citing Constitutional Topic: Official Language, The U.S Constitution Online, http://www.usconstitution.net/consttop_lang.html (last visited Oct. 31, 2006)).

23. Carl Hulse, Senate Passes a Bill That Favors English, N.Y. TiMES, May 19, 2006, at A18. 
national language of the United States." ${ }^{24}$ Shortly thereafter, the Senate approved a second, slightly weaker provision known as the Salazar Amendment, after Colorado Senator Ken Salazar, declaring English to be the "common and unifying" language of the United States. ${ }^{25}$ Neither bill was approved by the House of Representatives.

Senator Inhofe recently introduced the National Language Act of 2008, which was placed on the Senate's calendar. While the bill sought to declare English the national language, it stated that it would not "prohibit the use of a language other than English." 26 A companion bill was proposed in the House of Representatives by Representative Peter King of New York. ${ }^{27}$

\section{State Official-English Laws in the Courts}

\section{English-Only Provisions: First Amendment Challenges}

This section discusses cases construing English-only provisions in state statutes and constitutions. As demonstrated below, these statutes run afoul of the First Amendment in that they require English to be the only language spoken by elected officials and government employees. Courts have consistently held that these English-only provisions are an unconstitutional restriction on citizens' rights to communicate with elected officials and constituents.

\section{a. Arizona's Official-English Amendment}

In 1987, Arizonans for Official English (AOE) proposed a ballot initiative to amend Arizona's state constitution to declare English the state's official language. ${ }^{28}$ In addition to declaring English the official language of ballots, public schools, and all government functions and actions, the amendment, Article XXVIII, states that all political subdivisions were to "'act in English and in no other language.", November of that year, the amendment was passed after receiving

\footnotetext{
24. Id.

25. Id.

26. National Language Act of 2008, S. 2715 110th Cong. (2008).

27. See Support the National Language Act of 2007, http://www.proenglish.org/issues/offeng/ 769.html (last visited Dec. 8, 2008).

28. Ruiz v. Hull, 957 P.2d 984, 987 (Ariz. 1998).

29. Id. (quoting ARIZ. CONST. art. XXVIII § 3(1)(a)).
} 
affirmative votes from only $50.5 \%$ of Arizona voters. ${ }^{30}$ Within two days of ratification of Article XXVIII, challenges to its constitutionality under the U.S. Constitution began. ${ }^{31}$

On November 10, 1988, Maria-Kelly F. Yniguez, an employee of the Arizona Department of Administration's Risk Management Division, brought suit against the State of Arizona in the U.S. District Court for the District of Arizona. ${ }^{32}$ Yniguez claimed that her job as an insurance claims manager regularly required her to speak in Spanish with persons who did not speak any English. ${ }^{33}$ She claimed that Article XXVIII's prohibition against acting in any language other than English could cause her to lose her job. ${ }^{34}$ Thus, Yniguez argued that Article XXVIII violated the First and Fourteenth Amendments to the U.S. Constitution.

The district court ruled that the amendment was "fatally overbroad" because it imposed a sweeping ban on the use of any language other than English. ${ }^{35}$ The Ninth Circuit affirmed the district court's finding, even though Yniguez's resignation from her position of employment to accept a different job arguably rendered the case moot. ${ }^{36}$

The United States Supreme Court granted certiorari, in part, to determine whether Yniguez's resignation rendered the case moot. In its decision, the Court repeatedly expressed dissatisfaction with both the district court and the Ninth Circuit's decision to rule on the case, stating that these courts had proceeded "without the benefit of the views of the Arizona Supreme Court." 37 The Court declared that "[f]ederal courts lack competence to rule definitively on the meaning of state legislation." ${ }^{38}$ Ultimately, the Court vacated the lower courts' decisions as moot, and expressed satisfaction that the Arizona Supreme Court would appropriately decide the issue in the then-pending case, ${ }^{39}$ Ruiz $v$. Hull. $^{40}$ In its holding, the Court specifically declined to rule on the validity of the amendment. ${ }^{41}$

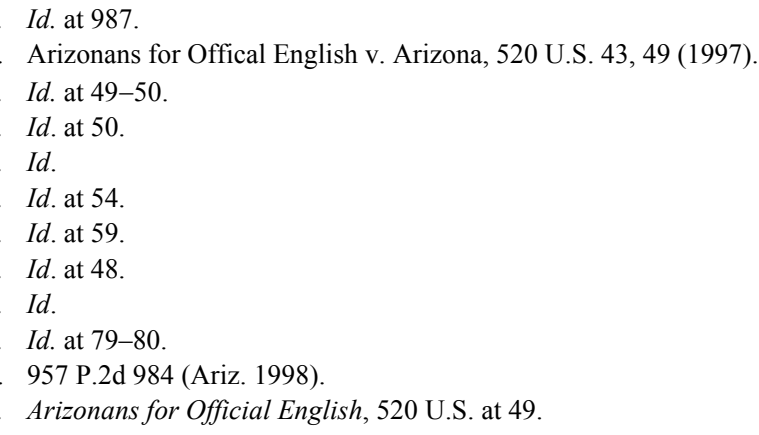


Ruiz v. Hull was filed by ten bilingual plaintiffs, including four elected officials, five state employees, and a public school teacher. ${ }^{42}$ Specifically, they brought the action against the Governor and Attorney General claiming Article XXVIII was unconstitutional because it prevented them from speaking Spanish in performing their government business. ${ }^{43}$ The trial court held that Article XXVIII did not violate the First Amendment because it was a content-neutral regulation, and, due to the lack of any evidence of discriminatory intent, it likewise did not violate the Fourteenth Amendment. ${ }^{44}$ The court of appeals reversed in part on the grounds that "judicial comity" required deference to federal litigation, specifically, the Ninth Circuit's decision in Arizonans for Official English v. Arizona. ${ }^{45}$ On further appeal, the Arizona Supreme Court addressed the merits of the case.

The Arizona Supreme Court began its decision recognizing that "in our diverse society, the importance of establishing common bonds and a common language between citizens is clear," and that "the acquisition of English language skills is important in our society." court found that unlike other states' Official-English provisions simply declaring English the official language, the Arizona provision explicitly prohibited government employees from using languages other than English, even when communicating with persons of limited English ability. ${ }^{47}$ The court found this to be an unconstitutional violation of the First Amendment because Article XXVIII "effectively cuts off governmental communication with thousands of limited-Englishproficient and non-English-speaking persons in Arizona." $" 48$

The Arizona Supreme Court rejected the government's argument that the First Amendment addresses the content of communication and not the mode. ${ }^{49}$ According to the court, "requiring that government officials communicate only in a language which is incomprehensible to nonEnglish speaking persons ... effectively bars communication itself" and therefore could not constitute a time, place, or manner restriction because, by its very nature, such a restriction suggests there are alternative means of communication. ${ }^{50}$ The court found that a corollary

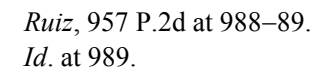


of the First Amendment's right to petition for redress of grievances was the "right to participate equally in the political process." 51 Additionally, the Arizona Supreme Court found that Article XXVIII violated the Fourteenth Amendment's Equal Protection Clause. The court subjected Article XXVIII to strict scrutiny on the grounds that it impinged upon fundamental First Amendment rights, and held that its "goal to promote English as the common language does not require a general prohibition on non-English usage., 52

Finally, having found the amendment unconstitutional, the Arizona Supreme Court declined to sever unconstitutional provisions in order to sustain the remainder of the amendment. ${ }^{53}$ The court determined that the valid portions of the amendment could be severed only if the court could determine from its language that the voters would have decided to enact the provision absent the unconstitutional portions. ${ }^{54}$ Finding no severability clause or evidence that the voters would have enacted the amendment without the unconstitutional portions, the court held that it was "not possible to sanitize the Amendment." 55

b. Oklahoma's Initiative Petition No. 366

In May of 2000, Oklahoma State Senator Carol Martin and State Representative Tom Kirby began Initiative Petition No. 366 to enact an Official-English statute in Oklahoma. ${ }^{56}$ Prior to its presentation to the electorate as a referendum, the Oklahoma Supreme Court conducted a "pre-election review" of the petition to determine whether it was constitutionally flawed. ${ }^{57}$ After determining that the petition was "fraught with infirmities," the court determined it would be "a disservice to the citizens of Oklahoma to submit a petition which could not withstand a constitutional attack to a state-wide vote."

As proposed, Initiative Petition No. 366 would declare English the official language of Oklahoma and require that "all official documents, transactions, proceedings, meetings and publications... be in English ...." Ad Additionally, the petition would "require the return to

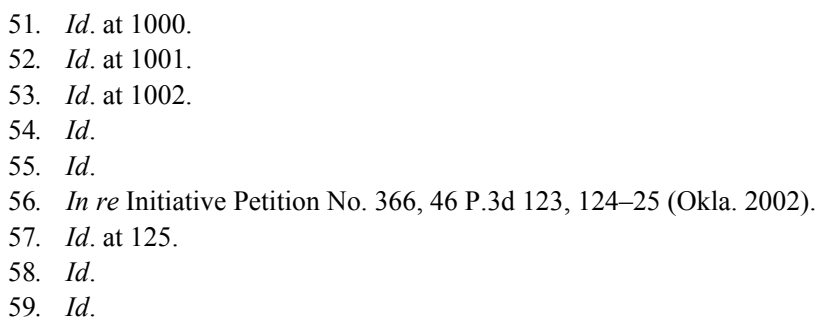


the general revenue fund all money" budgeted for the translation or printing of official materials in languages other than English. ${ }^{60}$ Finally, the petition provided exceptions for any conflicts with federal or state laws as well as for educational institutions. ${ }^{61}$

In its evaluation of the petition, the Oklahoma Supreme Court compared it to the Arizona provision that was deemed unconstitutional by the Ninth Circuit as well as the Arizona Supreme Court. ${ }^{62}$ The court found "that the Oklahoma Constitution is more protective of speech than is the United States Constitution." 63 The court determined that the language of the petition would "prohibit all governmental communications, both written and oral, by government employees, elected officials, and citizens, of all words, even those which are of common usage, in any language other than English when conducting state business." 64 Thus, the petition sought "to prevent citizens of limited English proficiency from effectively communicating with government officials and from receiving ... vital information about government." 65 Such a restriction would "disenfranchise segments of Oklahoma citizens by interfering with their ability to access vital information ... and cause self-censorship by inhibiting communications with government officials." $" 66$

\section{c. Alaska's Official-English Statute}

In 1998, the Alaskan non-profit corporation, Alaskans for a Common Language, Inc., sponsored a ballot initiative to make English the state's official language. ${ }^{67}$ Voters approved the initiative and it was codified in 1999. ${ }^{68}$ Thereafter, two separate groups of plaintiffs brought suit challenging the new law. The first group - the Kritz plaintiffs - was made up of three Togiak residents: a bilingual citizen, a bilingual elected official, and an elected official who spoke only the Yup'ik language. ${ }^{69}$ The second group of plaintiffs - the Alakayak plaintiffs - were residents of native villages who spoke either English and another language, or

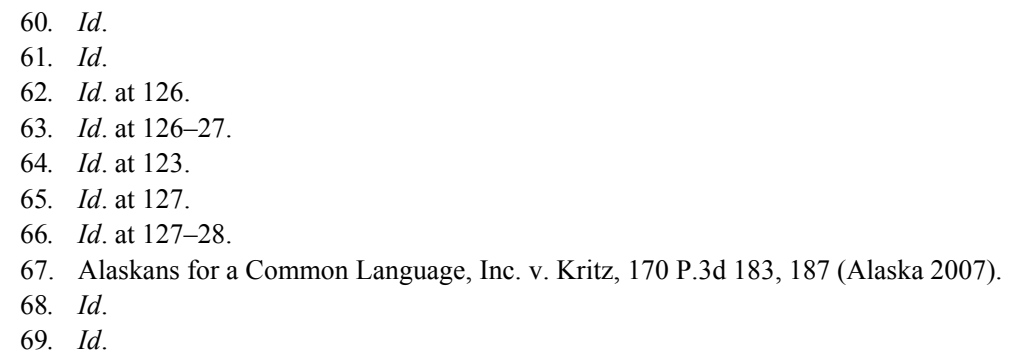


were unable to communicate in English at all. ${ }^{70}$ Both groups challenged the statute on the ground that it adversely affected their ability to communicate with or participate in government. ${ }^{71}$

The cases were consolidated and the superior court granted summary judgment in favor of the plaintiffs. ${ }^{72}$ That court rejected the defendants' argument that the initiative was "purely symbolic" and found the law to be unconstitutional. ${ }^{73}$ Ultimately, the court determined the initiative could not be saved by severing the unconstitutional provisions because it was not evident the voters would have approved the measure in that form. $^{74}$ Defendants appealed ${ }^{75}$ and the case was brought before the Supreme Court of Alaska.

The Supreme Court of Alaska began its analysis by taking notice that of the many Official-English statutes in place nationwide, the Alaska statute was most similar to the highly restrictive statutes struck down in Oklahoma and Arizona. ${ }^{76}$ The court concluded that the broad first sentence in the statute declaring English "the language to be used by all public agencies in all government functions and actions" "77 was unconstitutional because it "adversely affects the recipient speech rights of Alaska citizens with limited English proficiency" as well as their "ability to effectively petition the government."78 Additionally, the statute violated the rights of government officials because it barred them from helping citizens with limited English abilities secure government services and participate in civil life. ${ }^{79}$ While the state's interest in promoting unity among Alaskans through a common language is a compelling one, the court determined the English-only provision was not narrowly tailored to achieve its end. ${ }^{80}$

Unlike the determination made by the Arizona Supreme Court in Ruiz v. Hull, the Supreme Court of Alaska determined its OfficialEnglish statute could be salvaged by severing the unconstitutional part of the provision. ${ }^{81}$ Based largely on the existence of a severability clause in

\footnotetext{
70. Id.

71. Id. at $187-88$

72. Id. at 188 .

73. Id.

74. Id. at 189

75. Id.

76. Id.

77. Id. at 191

78. Id. at 202-03.

79. Id. at 204

80. Id. at 208 .

81. Id. at 209 .
} 
the statute, the court concluded severance was appropriate. ${ }^{82}$ By severing as unconstitutional the first sentence in the statute, the rest of the statute could remain valid and English would remain the official language of public documents and records compiled or published by the government. ${ }^{83}$

\section{Intermediate Provisions: Preserving English's Role}

This section addresses litigation stemming from the intermediary group of Official-English statutes. These statutes appear to be more than symbolic in nature, but do not go so far as to require English be the only language of government. Common to these statutes is a provision prohibiting state officials from enacting any law or provision that would diminish the role of English as the common language. As discussed below, these statutes do not run afoul of the Constitution, and are usually upheld. At the same time, courts have interpreted such provisions narrowly so as to allow government and government officials to accommodate limited-English proficient citizens.

\section{a. Alabama's Official-English Statute}

On June 5, 1990, Alabama voted to amend its state constitution to include an Official-English provision. ${ }^{84}$ As ratified, the amendment states in part:

English is the official language of the state of Alabama. The legislature shall enforce this amendment by appropriate legislation. The legislature and officials of the state of Alabama shall take all steps necessary to insure that the role of English as the common language of the state of Alabama is preserved and enhanced. The legislature shall make no law which diminishes or ignores the role of English as the common language of the state of Alabama. ${ }^{85}$

As a result of this amendment, the Alabama Department of Public Safety decided to administer state driver's license examinations solely in English. ${ }^{86}$ As part of the policy, the Department banned all use of

\footnotetext{
82. Id. at $212-13$.

83. Id. at 211-12.

84. See ALA. Const. art. I, § 36.01 (1990).

85. Id.

86. Alexander v. Sandoval, 532 U.S. 275, 279 (2001).
} 
interpreters, translation dictionaries, and any other interpretive aids. ${ }^{87}$ This decision led to a pair of cases whose holdings fall short of requiring the exams be administered in other languages, but which indicate that administering exams in languages other than English does not violate this provision.

In 1996, Martha Sandoval brought a class action in the U.S. District Court for the Middle District of Alabama to enjoin application of the English-only examination policy. ${ }^{88}$ Sandoval argued that the policy discriminated against non-English speakers based on their national origin in violation of Title VI of the Civil Rights Act of $1964 .{ }^{89}$ The district court found for Sandoval and granted the injunction. ${ }^{90}$ The Eleventh Circuit affirmed the district court's holding, stating that the "Englishonly official policy constituted a disparate impact on the basis of national origin." $" 1$

The United States Supreme Court granted certiorari and reversed. ${ }^{92}$ In its holding, the Court declined to rule on whether the previous courts were correct in their determination that the policy had the effect of discriminating on the basis of national origin. ${ }^{93}$ Rather, the Court addressed only whether the plaintiff in the case had a private cause of action under Title VI. Once the Court determined such a right of action did not exist, it reversed the lower courts' rulings.

Following the Eleventh Circuit's holding in Sandoval, the Department reversed its policy and began administering the exams in languages other than English. ${ }^{94}$ This prompted the second of the two cases construing the Alabama Official-English amendment. In response to the changes in the Department's policy, several members of the nonprofit organization "ProEnglish" filed suit against the Governor of Alabama and the director of the Alabama Department of Public Safety. ${ }^{95}$ The plaintiffs argued, given the Supreme Court's reversal of the Eleventh Circuit, the Sandoval holding - that the "English-only" driver's license examination policy violated Title VI—had no precedential value;

87. Sandoval v. Hagan, 197 F.3d 484, 488 (11th Cir. 1999), rev'd sub nom. Alexander v. Sandoval, 532 U.S. 275 (2001).

88. Sandoval v. Hagan, 7 F. Supp. 2d 1234, 1244 (M.D. Ala. 1998), aff'd, 197 F.3d 484, rev'd sub nom. Alexander v. Sandoval, 532 U.S. 275 (2001).

89. Id.

90. Id. at $1313-16$

91. Sandoval, 197 F.3d at 511.

92. Alexander, 532 U.S. at 294

93. Id. at 279

94. Cole v. Riley, 989 So. 2d 1001, 1004 (Ala. 2007).

95. Id. at 1002 . 
therefore, Alabama's current policy of offering the exam in languages other than English violated the Alabama Constitution. ${ }^{96}$

The defendants filed a motion for summary judgment on the grounds that the Eleventh Circuit's holding in Sandoval was still binding precedent because the case had been reversed on procedural grounds. ${ }^{97}$ In their response, the plaintiffs failed to make any evidentiary submissions to establish that the policy of "English-only" driver's license exams was necessary to preserve and enhance English as the official language, or that providing the exams in multiple languages led to its erosion. ${ }^{98}$ As a result, the trial court granted summary judgment in favor of the defendants. ${ }^{99}$ Finding itself bound by the same standard in its review, the Alabama Supreme Court affirmed on the grounds that the plaintiffs "failed to provide evidence creating a genuine issue of material fact as to whether multiple-language testing diminishes or erodes English as Alabama's common language or that English-only testing is necessary to preserve and enhance English as Alabama's common language."

\section{b. California's Official-English Amendment}

In 1986, California voters passed Proposition 63, which amended their state constitution to include an Official-English provision. The provision, article III, section 6, of the California Constitution, states in part:

English is the common language of the people of the United States of America and the State of California. This section is intended to preserve, protect, and strengthen the English language, and not to supersede any of the rights guaranteed to the people by this Constitution.... The Legislature and officials of the State of California shall take all steps necessary to insure that the role of English as the common language of the State of California is preserved and enhanced.

In 2001, the amendment's effect was the subject of litigation in a case against the California State Bar. Simon S. Levy filed a complaint against the California State Bar seeking an injunction against its production and

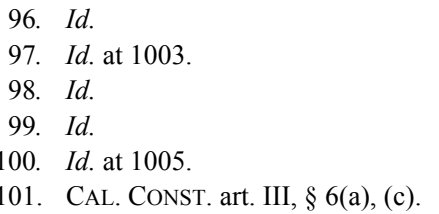


distribution of informational pamphlets in languages other than English. ${ }^{102}$ The two pamphlets specifically referred to in his complaint were published in Spanish. ${ }^{103}$ The first was an instructional pamphlet informing the reader what to do after an arrest. ${ }^{104}$ The second was merely a sheet of paper given to visitors of the State Bar Court explaining that they could be subject to search. ${ }^{105}$ Levy's theory was that article III, section 6, of the California Constitution precluded the State Bar from printing and distributing the pamphlets. ${ }^{106}$

The trial court granted summary judgment for the State Bar, finding that the California Constitution did not preclude the printing or distributing of materials in languages other than English. ${ }^{107}$ The Court of Appeals found that nothing in the language of the constitution precluded a "governmental body, such as the State Bar, from voluntarily printing and distributing consumer materials in languages other than English.",108 The court determined that the meaning of "official" language was that English was the "authorized" language, and that there was no indication from the amendment that "authorized" meant "exclusive." "I09 In sum, the court held that Levy erred in his failure to "distinguish between an entitlement and a voluntary governmental act." "The amendment did not preclude a governmental body from voluntarily printing and distributing materials in languages other than English.

\section{Symbolic Official-English Statutes}

The final section addresses litigation stemming from strictly symbolic Official-English statutes. Similar to the statutes in the last section, these statutes never run afoul of the Constitution. They are often cited by parties attempting to show a policy favoring English; however, they have never been extended to require government to act solely in English.

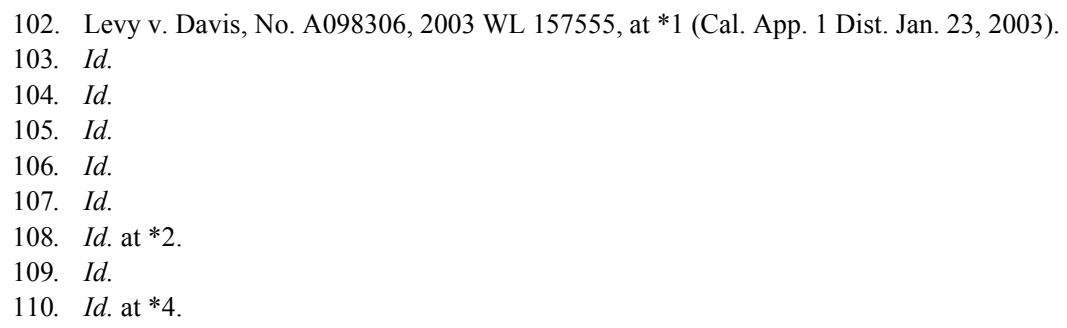


a. The Illinois Official-English Statute

In 1972, four individual plaintiffs along with the not-for-profit group Puerto Rican Organization for Political Action brought a class action against the Chicago Board of Election Commissioners to compel them to provide Spanish-language voter assistance at the upcoming November election. ${ }^{111}$ The four individual plaintiffs were Puerto Rican-born U.S. citizens who had been educated in Puerto Rico and did not know enough English to vote effectively without assistance. ${ }^{12}$ The district court granted an injunction requiring the requested language assistance; the Board appealed to the Seventh Circuit, in part, on the ground that the injunction would require them to violate the Illinois Official-English statute. $^{113}$

Defendants argued that the then-current provision declaring English the official language - along with naming the state bird and song - prohibited providing the voter assistance. ${ }^{114}$ After finding the superseded provision no longer effective, the court rejected such a strict application of the current provision stating that it had "never been used to prevent publication of official materials in other languages," and that "various state and city agencies publish numerous materials and provide many services in Spanish."

\section{b. Indiana's Official-English Statute}

On April 15, 1994, the Indiana Bureau of Motor Vehicles determined Jamie Vasquez to be a habitual traffic violator and suspended his license for ten years. ${ }^{116}$ Prior to this determination, Vasquez had been convicted three times for driving while intoxicated and once for leaving the scene of a personal injury accident. ${ }^{117}$ The notice of his ten-year suspension, written in English, was mailed to his residence. ${ }^{118}$ On June 5, 1994, Vasquez was stopped while driving and convicted of operating a vehicle after suspension for habitual traffic violations. ${ }^{119}$ He appealed his

111. Puerto Rican Org. for Political Action v. Kusper, 490 F.2d 575, 576 (7th Cir. 1973).

112. Id.

113. Id. at 576-77.

114. Id. at 577 .

115. Id.

116. Vasquez v. State, 700 N.E.2d 1157, 1157-58 (Ind. Ct. App. 1998).

117. Id. at 1157.

118. Id. at 1158 .

119. Id. 
conviction on the grounds that the suspension was not valid because the notice he received was in English and he could not read English. ${ }^{120}$

At the outset of its analysis, the court noted that Indiana Code section 1-2-10-1 declared English to be the official language of Indiana. ${ }^{121}$ Additionally, by statute, the driver's license examination included a test of one's ability to adequately read and understand traffic signs, and Indiana Code section 9-24-2-3(a)(4) prohibited issuance of a license to any individual who could not understand highway warning signs. ${ }^{122}$ In its ultimate holding, the court made an analogy to the Ninth Circuit's hesitation in previous cases to require the government to prepare all INS forms in both English and Spanish. ${ }^{123}$ Ultimately, the court held that the Indiana Bureau of Motor Vehicles was not required "to determine whether its drivers are literate, and if so, in what language."124

\section{c. Florida's Official-English Provision}

In the 1988 general election, Florida voters amended the state constitution to include an Official-English provision. ${ }^{125}$ The amendment contains little more than a statement that "English is the official language of the State of Florida."126

At the time the amendment was codified, Dade County had in place an "anti-bilingual" ordinance that had been adopted in 1980 through the ballot initiative process. ${ }^{127}$ The Dade County Commission thereafter passed Dade County Ordinance No. 93-46, which repealed the "antibilingual" ordinance. ${ }^{128}$ This action was challenged in the Dade County Circuit Court, in part on the grounds that repealing the "anti-bilingual" ordinance violated the Official-English provision in the Florida Constitution. ${ }^{129}$ Both the circuit court and the Florida District Court of Appeal held that repealing the "anti-bilingual" ordinance did not violate the amendment. ${ }^{130}$

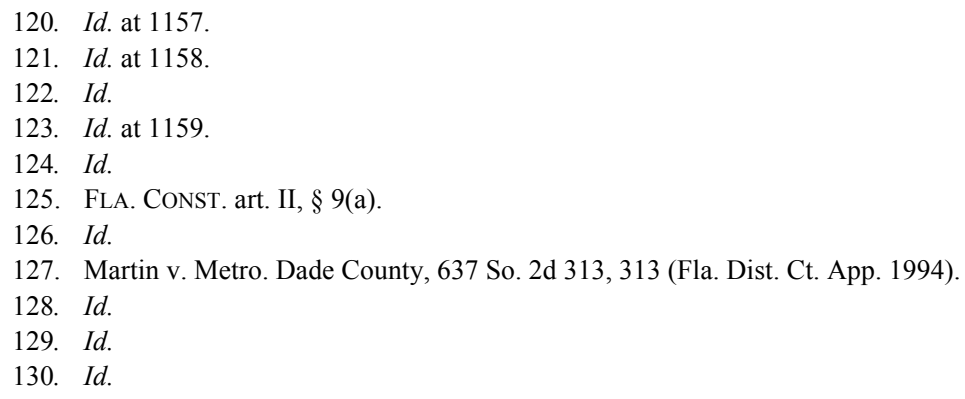




\section{Conclusion}

Despite consistent attempts since the early 1980s, Congress has never definitively established English as the official language of the United States. On the other hand, over thirty states have passed some form of Official-English legislation. These state laws fall into one of three categories: English-only laws which preclude the use of languages other than English in government affairs, intermediary statutes establishing a policy of enhancing the use of English within the state, and symbolic statutes merely declaring English to be the official language. While all have been litigated, it is the first group of statutes that has consistently been struck down by the courts as unconstitutional restrictions on citizens' rights to communicate with elected officials and constituents.

\section{LANGUAGE REGULATION AND VOTING LAWS}

\section{A. Introduction and Background}

In 1975, in response to evidence of continued voter discrimination against language minority voters, Congress amended the Voting Rights Act of 1965 to include language assistance provisions. ${ }^{131}$ These provisions - $\S \S 4(\mathrm{f})(4)$ and 203-identify jurisdictions in which language assistance is required, and specifically mandate that written voting materials in the applicable language be provided at "all stages of the electoral process." 132 As of 2006, the Act required roughly 500 political subdivisions from thirty-one states to provide bilingual voting assistance. $^{133}$ Five states-Alaska, Arizona, California, New Mexico, and Texas - are required by the Act to provide bilingual voter assistance statewide. $^{134}$

There are two triggering statutes that could subject a jurisdiction to the language assistance provision of the Voting Rights Act. Under $\S$ 4(f)(4), a jurisdiction is subject to the Act if three criteria were met as of November 1, 1972. ${ }^{135}$ These criteria include: (1) over five percent of

\footnotetext{
131. James Thomas Tucker, The Politics of Persuasion: Passage of the Voting Rights Act Reauthorization Act of 2006, 33 J. LEGIS. 205, 223 (2006).

132. Id. at 224-25 (citing 28 C.F.R. § 55.15 (1976)).

133. Editorial, Yes on Bilingual Ballots: Encourage Non-English Speakers To Make Informed Choices, WASH. Post, July 10, 2006, at A16.

134. Id.

135. Tucker, supra note 131, at 224.
} 
voting age citizens were members of a single language group; (2) the jurisdiction used English-only election materials; and (3) less than fifty percent of voting age citizens were registered to vote or voted in the 1972 Presidential election. ${ }^{136}$

The second triggering provision, $\S 203$, applies to a given jurisdiction if the Director of the Census makes two determinations. First, that "the limited-English proficient citizens of voting age in a single language group: (a) number more than 10,000; (b) comprise more than five percent of all citizens of voting age; or (c) comprise more than five percent of all American Indians of a single language group residing on an Indian reservation," and second, that the illiteracy rate of the language minority citizens in the jurisdiction exceeds the national illiteracy rate. ${ }^{137}$ The provision begins with Congress's express finding and declaration:

[T] hrough the use of various practices and procedures, citizens of language minorities have been effectively excluded from participation in the electoral process. Among other factors, the denial of the right to vote of such minority group citizens is ordinarily directly related to the unequal educational opportunities afforded them resulting in high illiteracy and low voting participation. The Congress declares that, in order to enforce the guarantees of the fourteenth and fifteenth amendments to the United States Constitution, it is necessary to eliminate such discrimination by prohibiting these practices, and by prescribing other remedial devices.

The provision defines persons of "limited-English proficiency" as those who speak English "less than very well" and would need assistance to participate effectively in the political process. ${ }^{139}$

If a jurisdiction meets the requirements of $\S 203$, when it provides "any registration or voting notices, forms, instructions, assistance, or other materials or information relating to the electoral process, including ballots, it shall provide them in the language of the applicable minority group as well as in the English language." 140 Where the language of the group is oral, or as in the case of Alaskan natives and American Indians, the language is historically unwritten, § 203 requires that the state or political subdivision "furnish oral instructions, assistance, or other

\footnotetext{
136. Id.

137. $I d$.

138. Voting Rights Act of $1965 \S 203,42$ U.S.C.A. § 1973aa-1a(a) (2003).

139. Tucker, supra note 131, at 224.

140. 42 U.S.C.A. § 1973aa-1a(c).
} 
information relating to registration and voting."141 In sum, this section prohibits these jurisdictions from conducting their elections solely in English.

\section{B. Litigation of Federal Regulations Regarding Bilingual Ballots and Voting Materials}

In Chinese for Affirmative Action v. Leguennec, ${ }^{142}$ the Ninth Circuit held that a good faith effort is not a defense to violations of the Voting Rights Act. In that case, Chinese and Spanish speaking plaintiffs brought an action alleging that the City of San Francisco failed to comply with the bilingual election provisions in the Voting Rights Act. ${ }^{143}$ The defendants argued that the city's failure to comply was reasonable because it was not deemed to be covered by the Act until September and had "only a few days in which to make the contracts and accomplish the changes necessary to modify its election procedures to comply with the Act before the November elections." 144 The court held that good faith was not an applicable defense and that shortage of time would not "shield election officials from the diligent assertion of rights under the Act" because it was Congress's intent to "eradicate voting discrimination with all possible speed." 145

Litigation often stems from the confusion over what materials the Voting Rights Act requires be translated in covered jurisdictions. For example, in In re County of Monterey Initiative Matter, ${ }^{146}$ a group of Spanish-speaking citizens brought suit against Monterey County, California, for failing to circulate an initiative petition and accompanying materials in Spanish. Monterey County was covered under $\S 203$ of the Voting Rights Act and as a result was required to provide ballots and other voting materials in Spanish. ${ }^{147}$ A group of citizens began an initiative petition to amend certain zoning and land development provisions. ${ }^{148}$ The county approved the form and content of the initiative for circulation among voters and provided it and accompanying summary

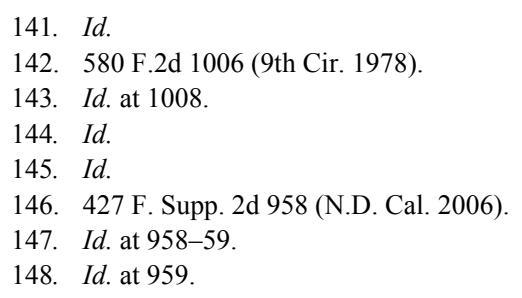


materials to be published in the newspaper; however, the initiative was never published in Spanish. ${ }^{149}$

The court determined that the case broke down into two primary questions: "(1) whether the materials qualify as "other materials or information relating to the electoral process' and (2) whether the materials are "provided by' the county." 150 In response to the first question, the court concluded that the title and summary materials prepared by the county did fall under the Act because these materials served "no purpose other than to impartially inform the voters of the content and effect of the proposed Initiative."151 In response to the second question, the court concluded that "the County's control of form and content of initiative petitions constituted extensive regulation" making the materials such that the County should provide them in Spanish as well as English. ${ }^{152}$

In addition to private parties, the United States may bring an action to enforce the Voting Rights Act's language provisions. For example, in United States v. Metropolitan Dade County, Florida, ${ }^{153}$ the United States brought an action challenging Dade County, Florida's decision to print an election information pamphlet solely in English. The informational pamphlet stemmed from special run-off elections that were to be held in districts where candidates had not received a majority vote. ${ }^{154}$ Prior to the special elections, Dade County determined it would benefit voters to mail out pamphlets explaining the elections. ${ }^{155}$ Despite being subject to $\S 203$ of the Voting Rights Act, Dade County determined the Act did not apply to the informational pamphlets, and refused to print them in Spanish. ${ }^{156}$

The district court rejected the county's claim, finding that the "pamphlet is covered under the plain language of Section 203 as 'assistance or other materials or information relating to the electoral process." "157 As support, the court cited 28 C.F.R. $§ 55.14$, which states that the applicable language in $\S 203$ " should be broadly construed to apply to all stages of the electoral process, from voter registration through activities related to conducting elections, including for example

149. Id.

150. Id. at 962 (quoting Voting Rights Act of $1965 \S 203,42$ U.S.C.A. § 1973aa-1a(c) (2003)).

151. Id. at 963 .

152. Id. at 964

153. 815 F. Supp. 1475,1477 (S.D. Fla. 1993).

154. Id. at 1476.

155. Id.

156. Id. at 1478 .

157. Id. 
the issuance, at any time during the year, of notifications, announcements, or other informational materials...."158 The court found that the pamphlet not only explained the election, but also contained relevant information regarding when and where voters should register. ${ }^{159}$ Therefore, the court concluded that the pamphlet qualified under the Voting Rights Act and the county's failure to provide the pamphlet in Spanish was a violation of the Act. ${ }^{160}$

\section{State Legislation Regarding Bilingual Ballots and Voting Materials}

Many states have their own provisions regarding the use of ballots and other election materials in languages other than English. Some of these statutes refer expressly to the requirements mandated by the Voting Rights Act. ${ }^{161}$ Others follow the Voting Rights Act's general policy of identifying highly concentrated bilingual areas and establish their own requirements for accommodating voters in those areas. ${ }^{162}$ For example, one New Jersey statute requires that for "election districts in which the primary language of $10 \%$ or more of the registered voters is Spanish, the officer or officers whose duty it may be... to provide and furnish official ballots" shall provide voting instructions and ballots in Spanish. ${ }^{163}$ Similarly, in California, the Secretary of State is required to post election materials in Spanish or other languages when the number of residents of voting age in a county or precinct "who lack sufficient skills in English to vote without assistance ... equals 3 percent or more of the voting age residents." " 164 Other states, like Kansas, simply place upon the Secretary of State a responsibility to print ballots and other voting materials in languages other than English when he or she "deems it advisable." 165

\section{English Literacy and the Right to Vote}

In 1970, the California Supreme Court struck down article II, section 1 of the California Constitution on the ground that it violated the Equal

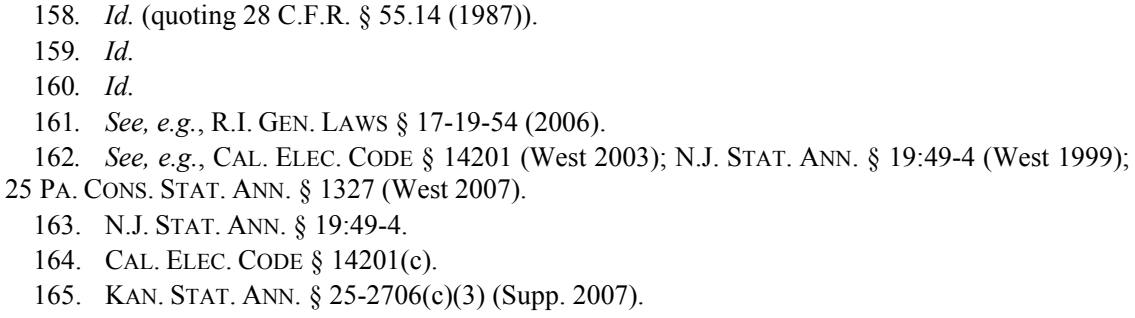


Protection Clause of the Fourteenth Amendment. ${ }^{166}$ That provision provided that " "no person who shall not be able to read the Constitution in the English language and write his or her name, shall ever exercise the privileges of an elector in this State." 167 The case was brought by two native born U.S. citizens residing in Los Angeles who were denied voter registration based on the fact that, while they could read Spanish, they were unable to read English. ${ }^{168}$ The plaintiffs brought an action seeking to have the court declare the provision unconstitutional, require the defendants to register them to vote, and require the defendants to print a reasonable number of ballots in Spanish to facilitate their ability to vote. $^{169}$

The plaintiffs provided evidence that they had access to Spanish language periodicals, newspapers, and other forms of media from which they could become informed on political issues. ${ }^{170}$ They also argued that the historical purpose of the English literacy voting requirement was to disenfranchise immigrant voters. ${ }^{171}$ The defendant did not challenge either of those issues, but provided evidence of a list of schools in Los Angeles at which English was taught to non-English speaking adults at no cost. ${ }^{172}$ Based on the pleadings, the trial court found for the defendants and rejected the plaintiffs' claim that persons literate only in Spanish would be able to adequately "familiarize themselves with political candidates and issues from Spanish-language news media."173

The California Supreme Court reviewed the case to determine "whether the challenged provision [was] compatible with the demands of equal protection as they apply in contemporary society."174 The court found that the issue in this case was not "the general question of a nondiscriminatory literacy requirement," but rather "a provision which discriminates among literate citizens, disenfranchising all who are literate in languages other than English." ${ }^{175}$ Thus, the issue became whether California's desire for intelligent and independent voters "may be satisfied by the exclusion of those of its citizens who, while unable to read the dominant language, English, nonetheless have access to, and the

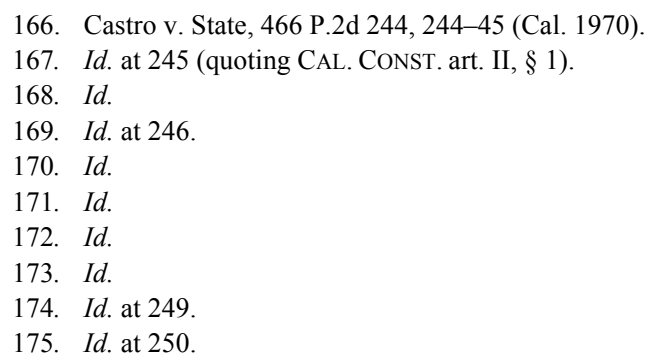


ability to utilize, those materials available through Spanish language publications."176

The court subjected the provision to strict scrutiny to determine whether restricting the right to vote to those literate only in English was necessary to achieve the compelling state interest in voters who are "capable of informed decisions on matters submitted to the electorate."177 The court went on to determine that the plaintiffs' evidence that they had access to seventeen Spanish language newspapers and eleven Spanish magazines was sufficient to demonstrate "access to materials printed in Spanish which communicate substantial information on matters, not only of national, but also of state and local political concern."178 It then held that as applied to the plaintiffs, the English literacy requirement violated their rights to equal protection. ${ }^{179}$ The court specifically expanded its holding to any case where "otherwise qualified prospective voters, literate in a language other than English, are able to make a comparable demonstration of access to sources of political information." "180

\section{E. Conclusion}

As of 2006, the Voting Rights Act required roughly 500 political subdivisions from thirty-one states to provide bilingual voting assistance. ${ }^{181}$ Many states that are not required to provide bilingual ballots under the Voting Rights Act have passed their own legislation incorporating the Act's requirements to their own local elections. Much of the litigation in this area stems from the confusion over what materials the Voting Rights Act requires be translated in covered jurisdictions.

\section{LANGUAGE AND EDUCATION}

\section{A. Introduction and Background}

America is a nation with a multilingual population. America is also a nation that places a high emphasis on elementary and secondary education. There are inherent difficulties in attempting to provide an education to non-English speaking students in the English language.

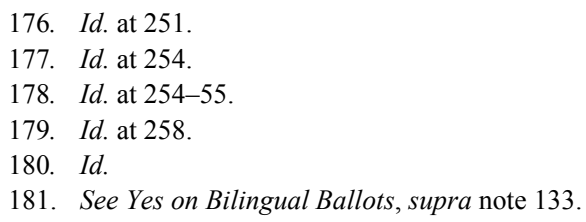


Immigration patterns are bringing "unprecedented diversity in cultural background[s] and languages" into the public education system in every state. ${ }^{182}$ The number of students with limited English proficiency in U.S. schools has "risen dramatically." 183 These students face a number of obstacles in attempting to assimilate into American schools, the most obvious of which is their lack of English competence. ${ }^{184}$ Language instruction transmits an important tool from an authority figure to a child. ${ }^{185}$ A vital element of an education is the recognition of authority figures, but if a student cannot understand authority figures, this element is unsatisfied. Studies show that students who do not understand the language in class and who cannot communicate effectively with teachers are more likely to dropout or fall behind because they cannot effectively participate in the education program. ${ }^{186}$

In Brown v. Board of Education, ${ }^{187}$ a unanimous Supreme Court stated that "education is perhaps the most important function of state and local governments."188 Public schools are charged with the daunting task of educating children who speak little or no English, as public schools "bear the chief responsibility for cultivating individuals capable of participating in society." "189 Education of English-learning children poses several significant problems, many of which will be discussed in this portion of the survey. Specifically, Part B will explore the bilingual education debate, Supreme Court jurisprudence dealing with rights of English-learning students, and two federal statutes that impact the education of English-learning students. Part $\mathrm{C}$ provides an analysis of a recent national news-making federal court case that arose when a middle school required its students to speak solely in English during school hours. This portion ultimately concludes that states are afforded wide latitude to pursue or not pursue bilingual education and that satisfying

182. Marcelo Suárez-Orozco, Peter D. Roos \& Carola Suárez-Orozco, Cultural, Educational, and Legal Perspectives on Immigration: Implications for School Reform, in LAW AND SCHOOL REFORM: SiX STRATEGIES FOR PROMOTING EDUCATIONAL EQUiTY 162 (Jay P. Heubert ed., 1999).

183. Jana Echevarria et al., School Reform and Standards-Based Education: A Model for English-Language Learners, 99 J. EDUC. RES. 195, 196 (2006).

184. Note, Federal Funding for Newcomer Schools: A Bipartisan Immigrant Education Initiative, 120 HARV. L. REV. 799, 799 (2007) (arguing that the lack of formal education in the students' native countries also represents a substantial obstacle).

185. Cristina M. Rodriguez, Language and Participation, 94 CAL. L. REV. 687, 760 (2006).

186. See AdVOCATES FOR CHILDREN OF NEW YoRK AND THE NEW YORK IMMigRATION COALITION, CREATING A Formula FOR SuCCESS: Why ENGLiSh LANGUAGE LEARNER STUdENTS ARE DROPPING OUt OF SCHOOL, AND HOW TO INCREASE GRADUATION RATES 16-17, $27-28$ (2002), available at $\mathrm{http}: / / \mathrm{www}$.advocatesforchildren.org/pubs/formulaforchange.doc.

187. 347 U.S. 483 (1954).

188. Id. at 493 .

189. Rodriguez, supra note 185 , at 758. 
the constitutional and statutory standards for the education of Englishlearning students, especially in light of the No Child Left Behind Act, may not be as difficult as it once was.

\section{B. Rights of English-Learning Students}

Statistics demonstrate that the public education system is growing at a steady pace. According to the Department of Education's website, a record 49.8 million students are attending public schools as of fall 2008. ${ }^{190}$ The public school systems are expected to employ about 3.3 million teachers during the 2008-2009 academic year, "resulting in a pupil/teacher ratio of 15.3."191 In the United States, "there are about 14,200 public school districts containing about 97,000 public schools."192 Additionally, projected expenditures for public schools during the 20082009 school year will be around $\$ 519$ billion, with a national average expenditure per student around $\$ 10,418 .^{193}$

As the system expands as a whole, children with limited English competency are becoming a greater proportion of school-age students. By 2030, non-native English speakers are expected to make up $40 \%$ of the school-age population. ${ }^{194}$ "Between 1979 and 2006, the number of school-age children (children ages 5-17) who spoke a language other than English at home increased from 3.8 million to 10.8 million, or from 9 to $20[\%]$ of the population in this age range." 195 Furthermore, almost three out of four of those children spoke Spanish. ${ }^{196}$ Statistics show that these Spanish-speaking children have a more difficult time learning English than children of other languages. Specifically, "[h]igher percentages of children who spoke Spanish or an Asian/Pacific Islander language at home spoke English with [more] difficulty (27 and 28[\%], respectively) than did those who spoke other Indo-European languages (19[\%]) or other languages (18[\%]) at home."197

\footnotetext{
190. NATIONAL Center fOr EduCATION Statistics, "FASt FaCts," http://nces.ed.gov/ fastfacts/display.asp?id=372 (last visited Feb. 3, 2009).

191. Id.

192. Id.

193. Id.

194. Celeste Roseberry-McKibiin \& Alejandro Brice, Am. Speech-Language-Hearing Ass'N, Acquiring English as a Second Language: What's "Normal," What's Not, http:// www.asha.org/public/speech/development/esl.htm (last visited Dec. 4, 2008).

195. See National Center for Education Statistics, Language Minority School-Age CHILDREN, http://nces.ed.gov/programs/coe/2008/section1/indicator07.asp (last visited Jan. 27, 2009).

196. Id.

197. Id.
} 
In general, the public school system is becoming more diverse. In $2006,43 \%$ of public school students were considered to be part of a racial or ethnic group, an increase from $22 \%$ in 1972 and $31 \%$ in $1986 .{ }^{198}$ Enrollment of Hispanic students in public schools was approximately $20 \%$ in 2006 - an increase of $14 \%$ since $1972 .{ }^{199}$ Similarly, "since 1986, the proportion of public school students who were Hispanic has increased more than the proportion who were Black or members of other minority groups." 200

English-language-learning students enter the public education system in the United States at every age, "possessing marginally to highly developed native language skills, little or no" English skills, and "sociocultural learning and experiences moderately to vastly different from" American society. ${ }^{201}$ Designing an effective curriculum for the vast array of English language learners is difficult, especially considering the "vast range of languages, degrees of native language and English proficiency, ... varying sizes and budgets of school districts, ... and the availability of trained bilingual educators in the multitude of languages." 202

Some school districts have responded to the needs of non-English speaking students by implementing bilingual education programs that instruct students equally in English and another language-typically the student's native language. Bilingual education will be addressed below. Other school districts have started "newcomer schools which cater exclusively to non-English-speaking immigrant[]" students. ${ }^{203}$ Newcomer schools help students learn English, learn about the American culture and how to balance the cultural environment at school with the native cultural environment at home, and learn academic content that will facilitate the student's transition into the mainstream classroom. ${ }^{204}$ Other school districts favor the "sink or swim" method, often called "English immersion." The perceived positives and negatives of each approach have been extensively debated. ${ }^{205}$

198. See National Center for Education Statistics, Racial/Ethnic Distribution of PUBLIC SCHOOL STUDENTS, http://nces.ed.gov/programs/coe/2008/section1/indicator05.asp (last visited Jan. 27, 2009).

199. Id.

200. Id.

201. William N. Myhill, The State of Public Education and the Needs of English Language Learners in the Era of 'No Child Left Behind,' 8 J. GENDER RACE \& JUST. 393, 419 (2004).

202. Id.

203. Note, supra note 184, at 799-800 (arguing that newcomer schools are the best solution but have failed because of a lack of adequate funding).

204. Id.

205. See generally id.; Rodriguez, supra note 185, at 758. 
Education of minorities in their ethnic language "represents the chief survival mechanism for a language, because in the educational context, a language's fate is sealed." 206 In Canada, a multilingual society like America, minority educational rights have garnered constitutional protections. $^{207}$ Minorities in the United States have not found such protections. ${ }^{208}$ Currently, the only language-based educational right is a statutory right of non-English speaking students to programs that assist them in overcoming language barriers, or the right to learn English. ${ }^{209}$ According to Meyer $v$. Nebraska, a state cannot prohibit the teaching of any language other than English without running afoul of the Fourteenth Amendment. ${ }^{210}$ Meyer noted that " $[\mathrm{t}]$ he protection of the Constitution extends to all, to those who speak other languages as well as to those born with English on the tongue." 211 States find very little constitutional guidance beyond Meyer in educating the unprecedented number of students with limited English skills in the public classroom.

The Supreme Court, addressing a federal civil rights statute, has noted that "students who do not understand English are effectively foreclosed from any meaningful education" and that schools must make reasonable efforts to accommodate such students. ${ }^{212}$ How to provide a "meaningful education" to non-English speakers is an issue that has puzzled educators and legislators for decades. Satisfying the "meaningful education" standard enunciated by the Supreme Court-and later codified in a federal statute - is a complicated and delicate process.

\section{The Bilingual Education Debate}

To understand the bilingual education debate, it is helpful to understand what is meant by the term "bilingual education." Broadly defined, bilingual education means "any use of two languages in school-by teachers or students or both-for a variety of social and pedagogical purposes." 213 The teaching methods widely vary:

206. Rodriguez, supra note 185 , at 758.

207. Part I of the Constitution Act, 1982, being Schedule B to the Canada Act 1982, ch. 11 (U.K.).

208. Some state constitutions afford students a right to an adequate education.

209. See, e.g., Lau v. Nichols, 414 U.S. 563 (1974) (holding that the school system's failure to provide English language instruction to students of Chinese ancestry who do not speak English violated the Civil Rights Act of 1964 while not reaching the question of whether it violated the Equal Protection Clause).

210. Meyer v. Nebraska, 262 U.S. 390 (1923).

211. Id. at 401 .

212. Lau, 414 U.S. at 566 (construing Title VI of the Civil Rights Act of 1964).

213. Nat'l Ass'n for Bilingual Educ., What Is Bilingual Education?, http://www.nabe.org/ 
[B]ilingual education methods vary and may involve classrooms with all [limited-English-speaking students], classrooms with a mix of [limited-English-speaking students] and native English speakers (who learn such languages as Spanish or Chinese), or a rapid (one to three years) or gradual (five to six years) transition to all-English classrooms. $^{214}$

Instruction may be in the native language and English or primarily in English with some native language support. ${ }^{215}$ The Supreme Court, construing a federal civil rights statute, has stated that states are not required to provide bilingual education, but may do so on their own initiative. $^{216}$

There are two dimensions to the bilingual education debate: English language acquisition and native language maintenance. ${ }^{217}$ Some argue that "effective pedagogy for the English language learner must target" both dimensions. ${ }^{218}$ Whether the public education system should be charged with perpetuating the multilingual character of American society is the crux of the bilingual education debate. Another crucial component of the debate is whether non-native speakers have the responsibility to learn English or whether the government must cater to their inability to do so. Who bears the burden - the students or the public education system - affects issues such as bilingual instruction and the strategies for integration of non-native students. The bilingual education debate has been called "the most explosive issue" in all of America's language debates. ${ }^{219}$ The dichotomy between the two sides of the debate can be staggering.

Proponents of bilingual education assert that bilingualism: (1) is necessary in a multicultural society; (2) helps students improve and maintain high academic achievement; and (3) is essential for ensuring that English language-learners have the same access to education afforded to native-English speakers. ${ }^{220}$ Opponents of bilingual education

education/index.html (last visited Jan. 13, 2009).

214. Bethany Li, Note, Poverty, Migration, and Trafficking in Persons: From Bilingual Education to OELALEAALEPS: How the No Child Left Behind Act Has Undermined English Language Learners' Access to a Meaningful Education, 14 GEO. J. ON POVERTY L. \& POL'Y 539, 544 (2007).

215. Nat'l Ass'n for Bilingual Educ., What Is Bilingual Education?, http://www.nabe.org/ education/index.html (last visited Jan. 13, 2009).

216. See generally Lau, 414 U.S. 563.

217. Rodriguez, supra note 185 , at 759 .

218. Myhill, supra note 201, at 404-05.

219. Rodriguez, supra note 185 , at 758.

220. See Jill Kerper Mora, A Road Map to the Bilingual Education Controversy, http://coe.sdsu.edu/people/jmora/Prop227/BERoadmap.htm (last visited Jan. 13, 2009). 
maintain that: (1) parents and not the schools should have primary responsibility for maintaining the students' native language; (2) bilingualism is an "impediment" to academic achievement; and (3) English immersion is more effective than bilingual education, especially considering the additional time and costs needed for bilingual education. $^{221}$ Bilingual education has been deemed an abject failure by critics; yet proponents believe that "[c]onsiderable research supports the conclusion that students in properly designed bilingual programs consistently outperform peers in English-only classrooms."222 There is no consensus among researchers as to the efficacy of a bilingual education.

In 1968, Congress began funding bilingual education programs through the Bilingual Education Act (BEA). ${ }^{223}$ The BEA was the "first official federal recognition of bilingual education" and was reauthorized in 1974, 1978, 1984, and finally in $1994 .^{224}$ The BEA encouraged states to "eliminate English-only instruction policies in schools" and provided funding for low income schools to develop bilingual programs that would transition limited English proficient students toward proficiency. ${ }^{225}$ A Supreme Court case, Lau v. Nichols, ${ }^{226}$ and a Fifth Circuit case, Castaneda v. Pickard, ${ }^{227}$ helped to clarify the requirements of federally-funded bilingual education programs by requiring schools to ensure that English-language-learning students obtain an education equal to that of native English speaking students, and by providing standards for appropriate language instruction programs. ${ }^{228}$

In the 1974 case of Lau v. Nichols, the United States Supreme Court held that "the San Francisco public schools violated their obligations under Title VI of the Civil Rights Act of 1964 by failing to provide programs for [limited-English] students of Chinese ancestry to assist them in learning English."229 Title VI bans discrimination based "on the ground of race, color, or national origin" in "any program or activity receiving Federal financial assistance," including public educational

\footnotetext{
221. See id.

222. Rodriguez, supra note 185 , at 761 n.284.

223. Li, supra note 214 , at 549 .

224. Id.

225. Alberto T. Fernandez \& Sarah W.J. Pell, The Right to Receive Bilingual Special Education, 53 EDUC. L. REP. 1067, 1069 (1989).

226. 414 U.S. 563 (1974).

227. 648 F.2d 989 (5th Cir. Unit A June 1981).

228. Li, supra note 214 , at 549 .

229. Rodriguez, supra note 185 , at 759.
} 
institutions. ${ }^{230}$ "The essential premise of Lau [is] that all students must have adequate access to English-language instruction."231 The Court stated that "there is no equality of treatment merely by providing students with the same facilities, textbooks, teachers, and curriculum; for students who do not understand English are effectively foreclosed from any meaningful education." 232 Subsequent cases have held that Lau does not require schools to provide limited-English students with a bilingualbicultural education; rather, schools need only " take affirmative steps to rectify language deficiencies." 233 When Lau required schools in 1974 to "overcome language barrier[s]," the Supreme Court did not mandate one "correct" education choice for children who spoke little English. ${ }^{234}$

Lau sparked an intense debate over how schools can fulfill their Title VI obligations. Some argue that Title VI requires bilingual education that includes native-language instruction, while others argue that English immersion classes are sufficient. ${ }^{235}$ "With one... exception, no court has held that Title VI requires bilingual education specifically." 236 Whether to provide a bilingual education is a choice left to individual states by popular vote. Some states have enacted laws requiring school districts to establish programs of transitional bilingual education for students of limited English-speaking ability. ${ }^{237}$

While Congress has never adopted legislation mandating an official national language, many states have adopted various forms of OfficialEnglish legislation and have mandated that English be the only instructional language used in public schools. ${ }^{238}$ Some argue that this type of instruction not only makes it difficult for non-English speaking children to receive meaningful education, but may also be detrimental to their familial and social integration. ${ }^{239}$ Only recently have states begun to prohibit schools from using non-English speaking students' native

\footnotetext{
230. Title VI of the Civil Rights Act of 1964, 42 U.S.C. § 2000d (2000).

231. Rodriguez, supra note 185 , at 759.

232. Lau, 414 U.S. at 566.

233. Guadalupe Org., Inc. v. Tempe Elementary Sch. Dist. No. 3, 587 F.2d 1022, 1029 (9th Cir. 1978) (quoting 35 Fed. Reg. 11,595 (1970)).

234. Lau, 414 U.S. at 568.

235. Rodriguez, supra note 185 , at 759 .

236. Id.; United States v. Texas, 506 F. Supp. 405 (E.D. Tex. 1981) (imposing bilingual education as remedy in school desegregation suit), rev'd, 680 F.2d 356 (5th Cir. 1982).

237. See, e.g., Filar v. Bd. of Educ., 526 F.3d 1054, 1056 (7th Cir. 2008).

238. See, e.g., TENN. CoDE ANN. § 4-1-404 (West 2007) (stating that English is to be the sole language of instruction in public schools). See generally supra Part II.

239. See Mei-Yu Lu, English-Only Movement: Its Consequences on the Education of Language Minority Children, 1998, http://www.eric.ed.gov/ERICDocs/data/ericdocs2sq1/content_storage_01/ 0000019b/80/29/c0/d4.pdf.
} 
languages in teaching them English and other subjects. ${ }^{240}$ While these native language bans, passed through popular referenda in at least three states-California, Arizona, and Massachusetts-may not impede English acquisition, they probably do impede native language retention. ${ }^{241}$

\section{Equal Educational Opportunities Act}

Congress essentially codified Lau's holding in enacting the Equal Educational Opportunities Act (EEOA). ${ }^{242}$ The statute provides that "[n]o state shall deny equal educational opportunity to an individual on account of his or her race, color, sex, or national origin, by the failure by an educational agency to take appropriate action to overcome language barriers that impede equal participation by its students in its instructional programs." ${ }^{243}$ As explained by the Ninth Circuit:

The EEOA was intended to remedy the linguistic discrimination identified by Lau ... , in which the Supreme Court held that failing to provide for the needs of non-English speaking students "is to make a mockery of public education," rendering classroom experiences for these children "wholly incomprehensible and in no way meaningful."

The EEOA mandates " "that schools are not free to ignore the need of limited English speaking children for language assistance to enable them to participate in the instructional programs of the district." 245 State education agencies have the obligation to supervise local districts to ensure compliance with the EEOA. ${ }^{246}$ While the EEOA does not require bilingual education, it does require states to expend resources to ensure that non-English speaking students receive an equal and meaningful education.

240. See ARIZ. Rev. Stat. § 15-752 (Lexis Nexis 2005) (“All children in Arizona public schools shall be taught English by being taught in English ...."); CAL. EDUC. CODE $\S 305$ (Deering 2005) ("All children in California public schools shall be taught English by being taught in English."); MASS. ANN. LAWS ch. 71A, $\S 4$ (Lexis Nexis 2005) (same).

241. See Rodriguez, supra note 185 , at 759.

242. Equal Educational Opportunities Act, Pub. L. No. 93-380, 88 Stat. 515 (codified as amended at 20 U.S.C. $\S \S 1703-58(1974))$

243. 20 U.S.C. $\S 1703(f)(2006)$.

244. Flores v. Arizona, 516 F.3d 1140, 1145-46 (9th Cir. 2008) (quoting Lau v. Nichols, 414 U.S. 563, 566 (1974)).

245. Id. (quoting Castaneda v. Pickard, 648 F.2d 989, 1008 (5th Cir. 1981)).

246. Idaho Migrant Council v. Bd. of Educ., 647 F.2d 69, 71 (9th Cir. 1981). 
The EEOA has been interpreted as "mandat[ing] remedial assistance to students with English language deficits, regardless of the number, '[a]s long as there is at least one person arguably denied equal educational opportunity." "247 The generally accepted elements of a violation of the EEOA are: "(1) the denial of educational opportunity on account of race, color, sex, or national origin; and (2) the educational agency's failure to take action to overcome language barriers that are sufficiently severe so as to impede a student's equal participation in instructional programs." ${ }^{248}$ Challenges to the EEOA often arise when plaintiffs oppose a state statute doing away with bilingual education. When opposing a state statute replacing a bilingual education system with an English immersion system, plaintiffs must establish that the English immersion system could not, in any circumstance, constitute "appropriate action" to overcome language barriers. ${ }^{249}$

In the litigation context, courts take a holistic look at the school system's operations relative to education of English-language-learning students. The analytical framework of the EEOA that was provided by the Fifth Circuit in Castaneda is three-fold:

First, courts must be satisfied that the school system is pursuing a program informed by an educational theory recognized as sound by some experts in the field or, at least, deemed a legitimate experimental strategy. Second, the programs and practices actually used by a school system must be reasonably calculated to implement effectively the educational theory adopted by the school. There must, in other words, be sufficient practices, resources and personnel to transform the theory into reality. Third, even if theory is sound and resources are adequate, the program must be borne out by practical results. ${ }^{250}$

After a violation is detected, courts have the power to institute measures that will remedy any illegality and bring programs into compliance with a "remedial decree tailored to address the specific violation." "251 Because precedents for defining an "appropriate" program are lacking, courts often rely on the Fifth Circuit's three-fold framework to evaluate challenges to a school district's education program under the EEOA. ${ }^{252}$

247. Heavy Runner v. Bremner, 522 F. Supp. 162, 164 (D. Mont. 1981) (quoting United States v. Sch. Dist. of Ferndale, 577 F.2d 1339, 1345 (6th Cir. 1978)).

248. Deerfield Hutterian Ass'n. v. Ipswich Bd. of Educ., 468 F. Supp. 1219, 1231 (D.S.D. 1979).

249. Valeria G. v. Wilson, 12 F. Supp. 2d 1007, 1017 (N.D. Cal. 1998).

250. Flores v. Arizona, 516 F.3d 1140, 1146 (9th Cir. 2008).

251. United States v. Texas, 523 F. Supp. 703, 737 (E.D. Tex. 1981).

252. Valeria G., 12 F. Supp. 2d at 1017 (stating that the leading circuit decision for determining 


\section{The No Child Left Behind Act}

The overarching emphasis of The No Child Left Behind Act $(\mathrm{NCLB})^{253}$ is English language proficiency. There are many who view NCLB as the federal government's attempt to do away with bilingual education. $^{254}$ NCLB, unveiled by President George W. Bush in 2001, renamed the "Bilingual Education Act" to the "English Language Acquisition, Language Enhancement, and Academic Achievement Act." 255 "NCLB ... [also] eliminated the Office of Bilingual Education and Minority Language Affairs and replaced it with the Office of English Language Acquisition, Language Enhancement, and Academic Achievement for Limited-English-Proficient Students" (OELA). ${ }^{256}$ NCLB's stated goals reflect a high priority on English acquisition and seem to neglect bilingual education, at least facially. ${ }^{257}$ NCLB aims "to help ensure that children who are limited English proficient, including immigrant children and youth, attain English proficiency, develop high levels of academic attainment in English, and meet the same challenging State academic content and student academic achievement standards as all children are expected to meet."258 To aid in this goal, NCLB provides grants to states with federal government-approved plans to benefit English-language-learning students. ${ }^{259}$

There is no explicit denunciation of bilingual education in NCLB. NCLB states that it seeks to ensure flexibility in the types of language instruction programs that state and local education agencies choose to teach students with limited English proficiency. ${ }^{260}$ NCLB "does not deal in the immediate, rights-based framework inherent in civil rights law, although it is intended to ameliorate over the longer haul the conditions that lead to civil rights violations." 261 Nothing in the NCLB "shall be construed in a manner inconsistent with any Federal law guaranteeing a

\footnotetext{
what "appropriate" means under $\S 1703(\mathrm{f})$ is Castaneda v. Pickard).

253. No Child Left Behind Act of 2001, Pub. L. No. 107-110, 115 Stat. 1425 (codified as amended in scattered sections of 20 U.S.C.).

254. See, e.g., Myhill, supra note 201, at 446 (discussing generally NCLB, and that it seems to repeal state and federal bilingual education).

255. James Crawford, Obituary: The Bilingual Education Act of 1968-2002 (2002), http:// ourworld.compuserve.com/homepages/JWCRAWFORD/T7obit.htm.

256. Myhill, supra note 201, at 426.

257. Li, supra note 214 , at 554 .

258. 20 U.S.C. $\S 6812(1)$ (2006).

259. Id. $\S \S 6821-26$.

260. Id. § 6812(9).

261. Flores v. Arizona, 516 F.3d 1140, 1173 (9th Cir. 2008).
} 
civil right." 262 The EEOA is an equality-based civil rights statute, while NCLB is a program for overall, gradual school improvement. ${ }^{263}$ "Compliance with the latter may well not satisfy the former." 264 "The EEOA's concerns, in other words, lie fundamentally with the current rights of individual students, while NCLB seeks to gradually improve their schools." 265 NCLB does not supersede the EEOA because the EEOA provides an express cause of action, while NCLB does not. ${ }^{266}$ The absence of remedies in NCLB leads courts to conclude that NCLB does not supersede the EEOA, but Congress could replace NCLB or insert a cause of action.

Because of its focus on English acquisition, some commentators see Congress's "incognito goal" in NCLB to squash federal support for bilingual education. ${ }^{267}$ These commentators believe that legislative initiatives to end bilingual education are unconstitutional or violative of the EEOA. ${ }^{268}$ While courts have held that the constitution neither requires nor prohibits bilingual and bicultural education, some argue that NCLB's focus on English acquisition - and perceived distraction from bilingual education - not only violates the EEOA but also reaches unconstitutional levels under the Equal Protection Clause.

\section{Rights of Schools and English-Only Rules}

Much has been written and discussed regarding English-only policies at the workplace. ${ }^{269}$ Whether a public school can require English to be spoken during school hours presents an intriguing legal question. A recent Wichita, Kansas lawsuit provides an opportunity to explore some of the issues educational institutions face in shaping English-only policies during school hours. The litigation also provides a context to expose uncertainties in constitutional, educational, and civil rights law.

The case involved a private parochial middle school. Although not a public school, much of the analysis should remain the same. Early in the 2007-2008 school year, St. Anne Catholic School required all students to

262. 20 U.S.C. $\$ 6847$.

263. Flores, 516 F.3d at 1172.

264. Id.

265. Id. at 1173.

266. Blessing v. Freestone, 520 U.S. 329, 348 (1997).

267. Li, supra note 214 , at 554-55.

268. See William Ryan, Note, The Unz Intiatives and the Abolition of Bilingual Education, 43 B.C.L. REV. 487 (2002); see also Myhill, supra note 201, at 447 (discussing an EEOA challenge in California after Proposition 227 denied bilingual services to limited English students).

269. See generally infra Part VI. 
speak English during school hours. ${ }^{270}$ Three sixth-grade students and their parents filed a complaint in federal court, alleging discrimination based on race, color, or national origin. ${ }^{271}$ The "plaintiffs claimed that St. Anne violated Title VI of the Civil Rights Act and 42 U.S.C. $§ 1981$ by intentionally discriminating against the sixth-graders . . causing a hostile educational environment." 272 St. Anne denied the allegations and asserted that the English-only rule was not discriminatory. ${ }^{273}$ St. Anne argued that the rule was "implemented as a legitimate and appropriate response to inappropriate behavior by a few [middle school] students." 274

St. Anne asserted that the case did not implicate constitutional or statutory rights, as no court has recognized a right to speak a foreign language at school. ${ }^{275}$ Classes at St. Anne are conducted in English and the three plaintiffs spoke fluent English. ${ }^{276}$ Because all three sixth-grade plaintiffs spoke English fluently, St. Anne claimed they were not deprived of access to any educational benefit or opportunity enjoyed by others; they were fully able to communicate with others, to give and take direction from others, and to learn in a safe environment. ${ }^{277}$ The court found for St. Anne after a one-week bench trial.

There is no constitutional or statutory entitlement for native English speakers to speak a foreign language during school hours. In Rubio $v$. Turner Unified School District No. 202, a federal court stated that it was "not aware" of "any case (Supreme Court, Tenth Circuit or otherwise) which establishes a right to speak a foreign language at a public school." 278 St. Anne was fortunate that all three student plaintiffs spoke English fluently. Had there been no alternative language of communication (other than Spanish), the case against St. Anne would have been much stronger. A school should be advised to have legitimate, nondiscriminatory reasons for requiring students to speak solely in English. Without such reasons, the rule can appear hostile and discriminatory. Reasonable excuses for an English-only rule might include issues of safety, the ability of teachers to understand students, and the promotion of unity and fellowship among students. Courts often

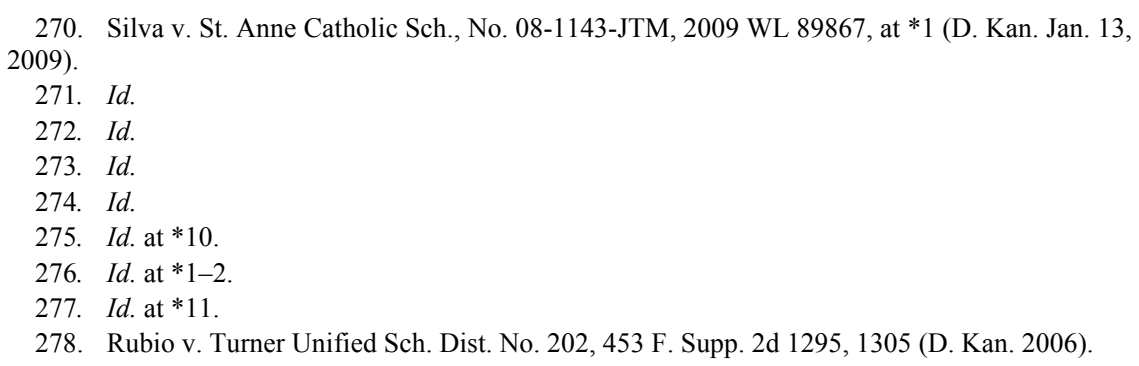


use the Title VII proof scheme for Title VI and $\S 1981$ claims of intentional discrimination. ${ }^{279}$

\section{Conclusion}

Because immigrant students have the "added obstacle of learning a new language while obtaining a meaningful educational experience,",280 their advocates have sought refuge in courts and in the legislature. Undoubtedly, the education of the limited English-speaking student population presents a pressing issue for educators, judges, and lawmakers. With the enactment of NCLB, advocates of bilingual education have an extra obstacle because of diminished federal funding for bilingual endeavors. States are in the best position to make decisions affecting the education of English-language-learning students. As long as states are making reasonable accommodations to English-language learners and are providing a meaningful and equal education to all students, the public education system satisfies its duties both under current constitutional precedents and federal legislation.

\section{LANGUAGE AND JURY SERVICE}

\section{A. Introduction and Background}

The "phenomenon of bilingual courtrooms" has caused legal problems of varying degrees and in varying forms. ${ }^{281}$ Language interpreters are utilized in federal and state courts much more often today than even a decade ago. ${ }^{282}$ "[T] $]$ provide meaningful access to justice, many court proceedings require interpretation of multiple languages in order to be comprehensible to all of the participants ....,283 Such interpretation enables a non-English speaking witness or party to testify in front of an English-speaking judge and jury. It is not difficult to see how a jury composed of jurors with limited English proficiency could produce a deficient verdict in civil or criminal cases. A defendant has the right to a jury that understands the proceedings. This section of the

279. See Guardians Ass'n v. Civil Serv. Comm'n of New York, 463 U.S. 582, 584, 586 (1983) (holding that proof of discriminatory intent is not necessary to establish a Title VI violation, at least for injunctive relief, and that Title VII disparate impact analysis is appropriate to Title VI claims).

280. Li, supra note 214 , at 540 .

281. See Marina Hsieh, "Language-Qualifying” Juries to Exclude Bilingual Speakers, 66 BROOK. L. REV. 1181, 1181-82 (2001) (discussing the challenges of bilingualism in courts).

282. Id. at $1182-83$.

283. Id. at 1183. 
survey will address the issues surrounding the statutory requirement that jurors possess a certain amount of English fluency. It will also touch on the authority of attorneys to strike jurors for a perceived lack of English competency and how such authority can be abused. This section concludes with a discussion of one unique fact pattern that permits attorneys to strike bilingual jurors.

Under the Sixth Amendment, all federal criminal litigants are entitled to trial by juries "selected at random from a fair cross section of the community in the district or division wherein the court convenes."284 The Supreme Court has recognized "a right to a jury composed of persons selected from a fair cross section of society" as a fundamental right. ${ }^{285}$ If non-English speakers are prohibited from serving on juries because of an inability to understand English, the question arises: are juries really adequate reflections of a fair cross section of the community? In most cases, the criminal defendant asserts that racebased exclusions of a juror violate his or her rights, but there is also a right of members of the community to serve on juries and not be excluded from them.

In Taylor v. Louisiana, ${ }^{286}$ the Supreme Court held that the Sixth Amendment right to a jury trial includes a requirement that "jury wheels, pools of names, panels, or venires from which juries are drawn must not systematically exclude distinctive groups in the community and thereby fail to be reasonably representative thereof." ${ }^{, 287}$ In Duren v. Missouri, ${ }^{288}$ the Court clarified the right:

In order to establish a prima facie violation of the fair-cross-section requirement, the defendant must show (1) that the group alleged to be excluded is a "distinctive" group in the community; (2) that the representation of this group in venires from which juries are selected is not fair and reasonable in relation to the number of such persons in the community; and (3) that this underrepresentation is due to systematic exclusion of the group in the jury-selection process.

284. Taylor v. Louisiana, 419 U.S. 522, 529 (1975) (quoting 28 U.S.C. $§ 1861$ (1970)).

285. See Stephen E. Reil, Comment, Who Gets Counted? Jury List Representativeness for Hispanics in Areas with Growing Hispanic Populations Under Duren v. Missouri, 2007 BYU L. REV. 201, 257 (arguing that this ideal "has gone largely unrealized" at least partly because of faulty data used to create the fair cross section).

286. 419 U.S. 522 (1975).

287. Id. at 538 .

288. 439 U.S. 357 (1979).

289. Id. at 364 . 
Even if a defendant establishes a prima facie case, no constitutional violation has occurred if the challenged exclusion serves "a significant [government] interest [that is] manifestly and primarily advanced by those aspects of the jury-selection process, such as exemption criteria, that result in the disproportionate exclusion of a distinctive group., 290

In the seminal case of Batson v. Kentucky, ${ }^{291}$ the Supreme Court reaffirmed the notion that the Equal Protection Clause of the Fourteenth Amendment forbids a "prosecutor to challenge potential jurors solely on account of their race...."292 Batson is consistent with other cases striking down racially prejudicial behavior. The more significant feature of Batson is what it said about proof of discriminatory intent. Before Batson, a challenger could not rely on statistical discrepancy to establish a prima facie case without some direct proof of intent. But under the Batson burden shifting formula, which resembles Title VII claims, this has changed. ${ }^{293}$ A key issue in Batson cases is whether it is a raceneutral explanation to say that jurors do not speak English. The line between language ability and race or national origin is hazy.

The question of whether language can be equated with race or national origin has received substantial attention in federal courts. ${ }^{294}$ No consensus has been reached. One decision used national origin and language interchangeably, ${ }^{295}$ another noted that language may be an "immutable characteristic" worthy of protection; ${ }^{296}$ yet another recognized that the Fourteenth Amendment protects groups of persons discriminated against because of linguistic characteristics. ${ }^{297}$ In some instances, language may be used as a pretext for racial discrimination. It is not hard to imagine a prospective juror being ostensibly removed for

290. Id. at $367-68$.

291. 476 U.S. 79 (1986).

292. Id. at 89 . The Court has applied the same analysis to forbid discrimination against individuals on the basis of gender. See J.E.B. v. Alabama, 511 U.S. 127, 146 (1994) (noting that "the Equal Protection Clause prohibits discrimination in jury selection on the basis of gender").

293. See Batson, 476 U.S. at $97-98$ (stating that once the defendant makes a prima facie showing, the State has the burden of showing "a neutral explanation related to the particular case to be tried").

294. See generally Andrew P. Averbach, Note, Language Classifications and the Equal Protection Clause: When is Language a Pretext for Race or Ethnicity?, 74 B.U. L. REV. 481 (1994) (discussing the relationship between language, race, and ethnicity in the context of the Equal Protection Clause).

295. See Espinoza v. Farah Mfg. Co., 414 U.S. 86, 92 n.5 (1973) ("There is no suggestion . . the company refused to hire aliens of Mexican or Spanish-speaking background while hiring those of other national origins.").

296. Garcia v. Gloor, 618 F.2d 264, 270 (5th Cir. 1980) (dictum).

297. United States v. Uvalde Consol. Indep. Sch. Dist., 625 F.2d 547, 553 (5th Cir. 1980). 
lack of English proficiency when race is the motivation for the juror's exclusion.

"Most courts have concluded that language classifications do not require heightened scrutiny." 298 This means that under the Equal Protection Clause, attorneys may potentially "strike bilingual persons from juries." 299 The "paradox is that language spoken does not fall within the protections of a Constitutional equal protection analysis, which may permissibly lead to racial discrimination."300 Attorneys may be striking jurors based on race while using language as a pretext.

\section{B. The Federal Jury Act and Comparable State Laws}

The Federal Jury Act provides that "[a] district court judge ... shall deem any person qualified to serve on grand and petit juries in the district court unless he ... is unable to read, write and understand the English language with a degree of proficiency sufficient to fill out satisfactorily the juror qualification form [or] is unable to speak the English language." $" 301$ The statute places the burden of determining a juror's fluency on the judge. ${ }^{302}$ A requirement of English proficiency prior to service on a jury is justified by the "overwhelming national interest served by the use of English in a United States court.", 303 One federal court applying the statute reasoned that "it is important that each juror be able to communicate verbally with the other jurors during deliberations .... To have one or more of them linguistically cordoned off from the debate would tend to cause some unacceptable attrition in the right to trial by jury ...." 304 Federal courts have consistently upheld the constitutionality of the Federal Jury Act, reasoning that the Act is subject to rational basis review. ${ }^{305}$ Many states have statutes equivalent

298. Colin A. Kisor, Using Interpreters to Assist Jurors: A Plea for Consistency, 22 CHICANOLATINO L. REV. 37, 46 (2001).

299. Id.

300. Id. at 47 .

301. 28 U.S.C. $§ 1865$ (b) (2000). The statute also requires the juror to be a U.S. citizen; be at least eighteen years old; have resided for a one-year period within the judicial district; not be incapable, by reason of mental or physical infirmity, to render satisfactory jury service; to not have a charge pending against him for the commission of, or to not have been convicted of a crime punishable by imprisonment for more than one year. $I d$.

302. Id. § 1865(a).

303. United States v. González-Vélez, 466 F.3d 27, 40 (1st Cir. 2006) (quoting United States v. Aponte-Suárez, 905 F.2d 483, 492 (1st Cir. 1990)).

304. United States v. McDade, 929 F. Supp. 815, 817 (E.D. Pa. 1996).

305. See, e.g., United States v. Arce, 997 F.2d 1123, 1127 (5th Cir. 1993) ("The constitutionality of $\S 1865$ (b) is subject to rational basis review.”). 
to the federal statute. ${ }^{306}$ In fact, all states except New Mexico include English proficiency as a qualification for jury service. ${ }^{307}$

There are several considerations offered to justify a requirement that jurors possess proficiency in English. First, English is the language of the court proceedings and the secret jury room deliberations. Some assert that an English proficiency requirement operates to exclude all persons who only speak Spanish. Assuming that persons who only speak Spanish constitute a "distinctive" group for purposes of the Sixth Amendment fair cross-section requirement, an English proficiency requirement is nonetheless constitutional because it manifestly advances significant government interests and is narrowly tailored. If jurors do not speak a common language, they cannot communicate among themselves, and communication is essential if jurors are to perform their deliberative function.

Next, English-speaking jurors are necessary to maintain the order and dignity of jury service. Some assert that an English proficiency requirement violates the fair cross-section requirement of the Sixth Amendment. However, many cities in the United States contain several different groups that are unable to speak English and that speak another language exclusively. If the jury venire must include all such groups in order to ensure that the jury pool includes a fair cross-section of the community, some chosen juries would likely require multiple translators. A jury composed in that way could probably not engage in the secret, deliberative process historically associated with a petit jury.

Yet another purpose for an English proficiency requirement is that translators are not allowed in the jury deliberation rooms. The use of translators could ensure effective communication among jurors who speak different languages; translators are commonly used in courtrooms to interpret party or witness testimony from a language other than English. Yet the Supreme Court has recognized that the presence of nonjurors in the jury room during deliberations "contravene[s] 'the cardinal principle that the deliberations of the jury shall remain private and

\footnotetext{
306. See DeLong v. Brumbaugh, 703 F. Supp. 399, 402 (W.D. Pa. 1989) (discussing Pennsylvania's jury qualification law); see also ALA. CoDE $\S 12-16-60(a)(2)$ (2006) (prospective juror must be "able to read, speak, understand and follow instructions given by a judge in the English language"); N.J. STAT. ANN. § 2B:20-1(b) (West 2008) (juror must "read and understand the English language"); N.C. GEN. STAT. ANN. § 9-3 (West 2000) (juror must be able to "hear and understand the English language"); McDade, 929 F. Supp. at 817 (allowing the voir dire question: "Do you have any difficulty reading or understanding the English language?").

307. G. Thomas Munsterman, Jury News, ¿ No Se Habla Jury Duty?, 2003, CT. MANAGER at 29, 30, available at http://www.ncsconline.org/WC/Publications/Res_Juries_JuryNewsEngHispRep Pub.pdf.
} 
secret.",308 Having a non-juror in the jury room also creates a serious risk that the course of deliberations will be influenced in ways that would be impossible to detect. ${ }^{309}$

Finally, running court proceedings in English preserves the uniformity federal courts seek. As the First Circuit has observed, "[f]ederal district courts in part are designed to provide trial alternatives for litigants, resident and nonresident, who seek the uniformity, expertise, and familiarity that they believe they may find in a national rather than a local forum." 310 An English proficiency requirement "is both symbolically and functionally significant in achieving this goal." 311

An English proficiency requirement "is the most subjective of all of the jury service qualifications." 312 "The others-U.S. citizenship, residency, age, and felony conviction status-are well-defined." When filling out the juror qualification questionnaire, prospective jurors mark either "yes" or "no" to each question. ${ }^{314}$ Courts vary greatly as to how they evaluate the English proficiency of a prospective juror. Some courts presume that a prospective juror "who completes the qualification questionnaire understands English sufficiently for qualification purposes." 315 Other courts use a jury staff to screen the language proficiency of prospective jurors. ${ }^{316}$ Any quick attempt to screen and judge a prospective juror's language fluency will fall short of giving a true picture of the person's abilities.

Several problems can arise by virtue of the flawed screening processes. First, "if the language screening process is over-inclusivethat is, if it is designed to include prospective jurors whose English proficiency is only marginal," then jurors who do not understand the proceedings will be included. ${ }^{317}$ The judge, if he or she catches the error, can excuse individuals who do not belong on the jury:

308. United States v. Olano, 507 U.S. 725, 737 (1993) (quoting FED. R. CRIM. P. 23(b) advisory committee's notes) (noting the effect of alternate jurors in the juror room).

309. See id. at 742 (Kennedy, J., concurring) (finding it "most difficult ... to show the absence of prejudice" from the presence of a thirteenth person in the jury room, because of "certain premises about group dynamics that make it difficult for us to know how the jury's deliberations may [be] affected").

310. United States v. Benmuhar, 658 F.2d 14, 20 (1st Cir. 1981).

311. Id.

312. Id.

313. Munsterman, supra note 307 , at 30.

314. Id.

315. Id.

316. Id.

317. Id. 
Judges may be able to screen more realistically because the expected level of trial complexity is generally better known at voir dire than at jury qualification. The risk of a juror having difficulty in understanding the testimony in the middle of a trial prompts judges to err on the side of increased proficiency. ${ }^{3}$

On the other hand, a jury should be a reflection of one's peers. If a judge uses a screening process that "is designed to disqualify Spanishspeaking (or other non-English speaking) [people] unless they [have fluent English abilities], then the jury panel appears to be less representative of the Hispanic population in the community than actually exists." 319 Such a case would be ripe for a "fair cross section" challenge under the Sixth Amendment. Striking a balance between a jury that understands English well enough to grasp the trial proceedings, on the one hand, and a jury that fairly represents society, on the other, is a process that varies in complexity by region.

\section{Special Case in Which Bilingual Jurors May Be Constitutionally Struck}

Consider the case where a potential juror is bilingual with English and Spanish fluency; the trial will include in-court testimony given in Spanish and translated into English by an interpreter. An attorney believes that the potential juror will not be able to focus solely on the English interpretation, but instead will listen to the Spanish testimony. The attorney wants to dismiss the potential juror from the pool.

Under Hernandez v. New York, ${ }^{320}$ lawyers may legitimately exclude bilingual jurors because they might listen to non-English testimony, not the court's official testimony in English. ${ }^{321}$ In Hernandez, prosecutors were allowed to strike potential jurors based on fluency in another language without violating Batson v. Kentucky because language and race, in this particular instance, could be distinguished. ${ }^{322}$ The prosecutor in Hernandez admitted "that he struck two prospective jurors who were bilingual in Spanish and English because he was uncertain they would listen to and follow the English interpreter during testimony

\footnotetext{
318. Id.

319. Id.

320. 500 U.S. 352 (1991).

321. See Kisor, supra note 298, at 45 (noting how the United States Supreme Court denied a defendant's equal protection challenge of the use of peremptory challenges to exclude bilingual

322. See Hernandez, 500 U.S. at 370-72 (noting that the prosecutor "offered a race-neutral basis for his exercise of peremptory challenges").
} jurors). 
in Spanish." 323 Hernandez noted the possibility that language may be a surrogate for race under an equal protection analysis. ${ }^{324}$ Circuit courts have followed Hernandez, accepting an ability to understand original, non-English testimony of a witness as a legitimate, non race-based reason for a peremptory strike of a juror. ${ }^{325}$

Hernandez has also been followed in state courts. For instance, the Texas Court of Appeals refused to overturn the conviction of a Spanishspeaking defendant where the prosecutor struck all the potential jurors who spoke Spanish. The prosecutor explained: "Based on my past experience in trying cases where there are interpreters involved, [the jurors] will not follow the official version of the interpreter.", However, in part because the prosecutor also struck two Caucasians who spoke Spanish, the court rejected the defendant's Batson challenge and found the prosecutor's actions to be race-neutral. ${ }^{327}$

\section{Conclusion}

Jury service is another context in which separation of race from language is vital because of the Constitution and federal laws. Attorneys must exercise caution when striking jurors for perceived inability to understand English at a necessary level. Striking a juror might trigger claims of race discrimination by the stricken juror or Sixth Amendment "fair cross section" claims by the criminal defendant. Not striking a juror, on the other hand, might lead to claims of an unfair trial if the juror did not possess sufficient English competency.

323. Id. at 356-57.

324. See id. at 371-72 (stating this did not resolve "the breadth with which the concept of race should be defined").

325. See Pemberthy v. Beyer, 19 F.3d 857 (3d Cir. 1994) (holding the Equal Protection Clause does not prohibit attorneys from peremptory challenges of bilingual jurors when their ability will allow them to understand a translation at dispute in the trial); United States v. Munoz, 15 F.3d 395 (5th Cir. 1994) (noting peremptory challenges of bilingual jurors is reasonable when the challenge is race neutral and tied to the particular circumstances of the case).

326. Chavarria v. Texas, No. 05-98-0595-CR, 2000 WL 567072, at*6 (Tex. App. May 9, 2000).

327. See id. at *6, *15; see also Kisor, supra note 298 , at 45 (noting the dismissal of two Caucasian Spanish-speaking jurors in addition to a Hispanic Spanish-speaking juror was relevant to the court finding the actions race-neutral). 


\section{LANGUAGE REGULATION IN THE WORKPLACE}

\section{A. Introduction and Background}

Since 1980, policies prohibiting the use of languages other than English in the workplace (workplace English-only policies) have spawned significant litigation. ${ }^{328}$ While claims under Title VII are by far the most common, ${ }^{329}$ English-only employment litigation has recently expanded into other areas of federal and constitutional law. ${ }^{330}$ Plaintiffs commonly argue that workplace English-only policies are discriminatory in violation of Title VII and $\S 1981$. Federal courts of appeals also recently considered, in a case of first impression, whether workplace English-only policies may violate the First Amendment. ${ }^{331}$ This section provides a summary of the caselaw and regulations that bear on whether workplace English-only policies violate federal law. Due to the relatively unsettled nature of these cases, it is difficult, if not impossible, to provide definitive answers to the issues that arise in English-only employment litigation. Nevertheless, this section provides a general overview of the issues that confront employees and employers in English-only employment litigation. In assessing the legality of a workplace English-only policy, courts may consider, inter alia, the effects the policy has on employees, the breadth of the policy, the employer's motivation for the policy, and whether business necessities justify the policy. Consequently, employers must fully consider the legal implications of adopting a workplace English-only policy.

\section{B. Federal and Constitutional Laws Bearing on the Legality of English- Only Policies}

Although the United States has long been a melting pot of nationalities and cultures, neither the Constitution nor any federal law directly proscribes language discrimination. ${ }^{332}$ Indeed, federal laws

328. See Harold S. Lewis, JR. \& Elizabeth J. Norman, EMPloyment Discrimination LaW AND PRACTICE 81 (2d ed. 2004) (stating that between 1996 and 2000, EEOC charges against workplace English-only policies quintupled).

329. Deborah F. Buckman, Annotation, Requirement that Employees Speak English in Workplace as Violative of Federal Constitutional and Statutory Law, 24 A.L.R. FED. 2d 587 (2007).

330. See, e.g., Maldonado v. City of Altus, 433 F.3d 1294, 1298 (10th Cir. 2006) (challenging a public workplace English-only policy as a violation of the First Amendment to the U.S. Constitution under 42 U.S.C. $\S 1983)$.

331. Id. at 1309 .

332. See Julie Thorpe-Lopez, America's Melting Pot: Language Not Included. U.S. Workplace Language Discrimination and the European Union Approach as a Model Framework, 38 CAL. W. 
bearing on the subject permit language discrimination-in the form of pre-hiring language competency or proficiency requirements-if necessary for effective job performance. ${ }^{333}$ Because language is not protected, plaintiffs must predicate discrimination claims against workplace English-only policies on violations of other federal laws which indirectly implicate language - such as those prohibiting discrimination or prohibiting restrictions on freedom of speech. Plaintiffs have therefore challenged the legality of workplace Englishonly policies as national origin discrimination in violation of Title VII of the Civil Rights Act of 1964, as racial discrimination in violation of the Civil Rights Act of 1966, $\S 1981$, and as a violation of the First Amendment to the U.S. Constitution. ${ }^{334}$ Workplace English-only policies may also implicate the anti-retaliation provisions of Title VII and $\S 1981 .^{335}$ The following sections first introduce the procedural frameworks that apply to the preceding theories of liability. Following this introduction is a discussion of the issues that arise when these theories of liability are applied to workplace English-only policies.

INT'L L.J. 217, 232 (2007) (noting language is not a protected class under Title VII).

333. See 42 U.S.C. $\S 2000$ e-2(e) (2000) (authorizing an employer to "hire and employ employees ... on the basis of his religion, sex, or national origin in those certain instances where religion, sex, or national origin is a bona fide occupational qualification reasonably necessary to the normal operation of that particular business or enterprise").

Note, however, that the Bona Fide Occupational Qualification affirmative defense does not "excuse discrimination in post-hire terms and conditions of employment-compensation, promotion, discipline, harassment or discharge - or any discrimination on the basis of race." LEWIS \& NORMAN, supra note 328, at 174; see also EEOC Compliance Manual, Section 13: National Origin Discrimination, No. 915.003, Dec. 2, 2002 (stating that language fluency requirements are permissible "only if required for the effective performance of the position for which it is imposed" and providing an example of a permissible refusal to hire due to lack of necessary language proficiency); Price Waterhouse v. Hopkins, 490 U.S. 228, 239 (1989) (discussing the need, under Title VII, to balance employee rights with employer prerogatives), superseded by statute, Civil Rights Act of 1991, Pub. L. No. 102-166, 105 Stat. 1071; Forsythe v. Bd. of Educ., 956 F. Supp. 927, 932-33 (D. Kan. 1997) (citing Garcia v. Spun Steak Co., 998 F.2d 1480, 1487 (9th Cir. 1993)) (stating that "language difficulties that interfere with performance of duties may be legitimately considered in employment decisions"); Cristina M. Rodríguez, Language Diversity in the Workplace, 100 Nw. U. L. REV. 1689, 1691 n.3 (2006) (stating that regarding the "English-only rule phenomenon, I am concerned not with the employer's setting of English fluency or proficiency as a condition of employment in the first place - it would be an uphill battle to demonstrate that an English-language requirement, in the majority of cases, is anything but a legitimate job requirement, or a bona fide occupational qualification"). But see Garcia v. Gloor, 618 F.2d 264, 269 (5th Cir. 1980) (stating that "[t]he refusal to hire applicants who cannot speak English might be discriminatory if the jobs they seek can be performed without knowledge of that language").

334. See, e.g., Maldonado, 433 F.3d at 1298; Spun Steak, 998 F.2d at 1483; Gloor, 618 F.2d at 266.

335. Maldonado, 433 F.3d at 1308. 


\section{Title VII Actions}

Title VII of the Civil Rights Act of 1964 proscribes racial and national origin discrimination. Under Title VII:

It shall be an unlawful employment practice for an employer-(1) to fail or refuse to hire or to discharge any individual, or otherwise to discriminate against any individual with respect to his compensation, terms, conditions, or privileges of employment, because of such individual's race, color, religion, sex, or national origin; or (2) to limit, segregate, or classify his employees or applicants for employment in any way which would deprive or tend to deprive any individual of employment opportunities or otherwise adversely affect his status as an employee, because of such individual's race, color, religion, sex, or national origin. ${ }^{336}$

By its terms, Title VII prohibits employment policies that adversely affect an employee's tangible job benefits or an employee's "terms, conditions, or privileges of employment" ${ }^{\prime 37}$ because of the employee's national origin. ${ }^{338}$ There are two major theories of liability under which a plaintiff may bring a Title VII claim - disparate treatment theory and disparate impact theory. ${ }^{339}$ Plaintiffs may also bring Title VII claims under a hostile work environment theory. ${ }^{340}$ The following subsections first discuss the burden-shifting frameworks applicable to Title VII disparate treatment and disparate impact claims. Following this discussion is an analysis of how courts have applied these burdenshifting frameworks to Title VII claims challenging workplace Englishonly policies. The final subsection then discusses whether a workplace English-only policy may create a hostile work environment for bilingual employees of non-English speaking national origins.

\section{Disparate Treatment Theory}

Plaintiffs alleging a violation of Title VII based on disparate treatment typically cannot recover when the alleged disparate treatment results from the adoption of a workplace English-only policy. A Title VII disparate treatment claim proceeds under the burden-shifting

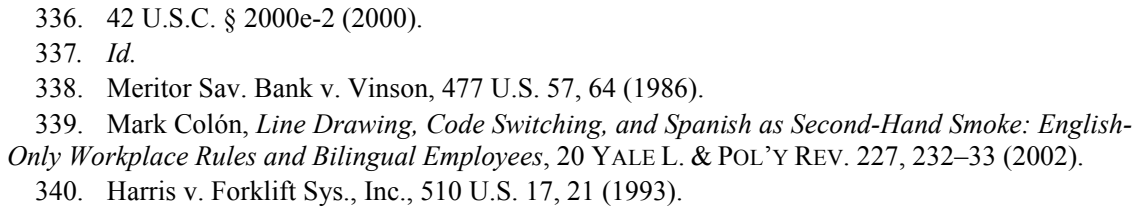


framework established in McDonnell Douglas Corp. v. Green. ${ }^{341}$ To establish a prima facie claim of disparate treatment, a plaintiff must prove (through direct or circumstantial evidence) that the employer's adoption of the English-only policy was motivated by discriminatory intent. $^{342}$ The burden then shifts to the employer to "articulate a legitimate, nondiscriminatory reason" for the employment policy. ${ }^{343}$ After the employer articulates a legitimate, nondiscriminatory reason for the policy, the burden shifts back to the employee to show that the policy is merely a pretext for discrimination. ${ }^{344}$

Although language is intimately related to national origin, Title VII does not prohibit discrimination on the basis of language. ${ }^{345} \mathrm{~A}$ workplace English-only policy is therefore facially neutral because it does not discriminate based on "race, color, religion, sex, or national origin." 346 Plaintiffs may nevertheless establish a prima facie case of discrimination by presenting sufficient direct or circumstantial evidence that the employer's adoption of the English-only policy was motivated by national origin-based animus. ${ }^{347}$ For example, some courts have held that workplace English-only policies which forbid the use of other languages at all times and make no exceptions provide sufficient circumstantial evidence of discriminatory intent to satisfy the plaintiff's initial burden of proving disparate treatment. ${ }^{348}$ If, however, a plaintiff cannot proffer any evidence showing that the employer adopted the English-only policy with the intention of adversely affecting protected

341. 411 U.S. 792, 802-04 (1973).

342. See id. at 802; Colón, supra note 339, at 233; Rosanna McCalips, What Recent Court Cases Indicate About English-Only Rules in the Workplace: A Critical Look at the Need for a Supreme Court Ruling on the Issue, 4 U. PA. J. LAB. \& EMP. L. 417, 418 (2002).

343. McDonnell Douglas Corp., 411 U.S. at 802.

344. Id. at 804 .

345. 42 U.S.C. $\S 2000 \mathrm{e}-2(2000)$.

346. Colón, supra note 339, at 233; Thorpe-Lopez, supra note 332, at 231.

347. Colón, supra note 339 , at 233 .

348. In the context of workplace English-only policies, courts typically base an inference of national origin-based animus on the EEOC guidelines, which presume that English-only policies that apply at all times violate Title VII. See, e.g., Barber v. Lovelace Sandia Health Sys., 409 F. Supp. 2d 1313, 1335-36 (D.N.M. 2005) (assuming, for the purposes of summary judgment, that an English-only rule that applied at all times establishes a prima facie claim of disparate treatment); EEOC v. Premier Operator Servs., Inc., 113 F. Supp. 2d 1066, 1076 (N.D. Tex. 2000) (holding that employees fired for noncompliance with English-only policy were entitled to recovery under Title VII). The rationale for these holdings is similar to the rationale articulated by the United States Supreme Court in Romer v. Evans. 517 U.S. 620, 632 (1996). In Romer, the Supreme Court struck down a state constitutional amendment that prohibited governmental action designed to protect homosexuals from discrimination. Id . at 622. The Court reasoned that the sheer breadth of the amendment was so misaligned with the reasons for the amendment that one must assume that the amendment was motivated by sexual orientation-based animus. Id. at 632 . 
classes, the plaintiff will be unable to establish a prima facie case. ${ }^{349}$ Consequently, narrowly-tailored English-only policies motivated solely by legitimate business reasons are unlikely to subject employers to liability under a disparate treatment theory. ${ }^{350}$ For this reason, most Title VII challenges to workplace English-only polices are brought under a disparate impact theory.

\section{Disparate Impact Theory}

Disparate impact claims challenging workplace English-only policies have been increasingly successful in recent years. ${ }^{351}$ Such disparate impact claims proceed under the three-step burden shifting framework established in Griggs v. Duke Power Co. ${ }^{352}$ According to the Griggs framework, the plaintiff must first establish that the employment policy in question has a disparate impact on members of a protected class. ${ }^{353}$ To establish a disparate impact, the plaintiff must prove that the policy has a significant, disproportionate, adverse impact on the "terms, conditions, or privileges of employment" of a protected class. ${ }^{354}$ Although plaintiffs typically present statistical evidence to satisfy the initial burden, plaintiffs may also use more subjective, qualitative forms of evidence. ${ }^{355}$ If the plaintiff satisfies his or her initial burden, the burden then shifts to the defendant employer to provide a business necessity for the policy. ${ }^{356}$ The employer's burden to justify the allegedly discriminatory policy with a business necessity is in the nature of an affirmative defense, which the employer may establish by presenting statistical reports, expert testimony, or prior successful experience that proves the discriminatory

349. See Maldonado v. City of Altus, 433 F.3d 1294, 1307-08 (10th Cir. 2006) (concluding that plaintiffs presented sufficient evidence of discriminatory intent to establish a prima facie disparate treatment claim).

350. See Montes v. Vail Clinic, Inc., 497 F.3d 1160, 1171 (10th Cir. 2007) (concluding a "policy applicable only at 'certain times' or places" is "justifiable on a showing of business necessity").

351. Compare Maldonado, 433 F.3d at 1316 (holding that plaintiff presented sufficient evidence that employer's English-only policy created a hostile work environment to render summary judgment inappropriate), with Garcia v. Gloor, 618 F.2d 264, 270 (5th Cir. 1980) (holding that employees failed to establish that employer's English-only policy caused a disparate impact in violation of Title VII).

352. 401 U.S. 424, 427-31 (1971); see also McCalips, supra note 342, at 418

353. McCalips, supra note 342, at 419.

354. Albemarle Paper Co. v. Moody, 422 U.S. 405, 425 (1975); Garcia v. Spun Steak Co., 998 F.2d 1480, 1486 (9th Cir. 1993) (citing Connecticut v. Teal, 457 U.S. 440, 446 (1982)).

355. See Maldonado, 433 F.3d at 1304-06 (explaining evidence of specific instances of "ethnic taunting as a result of the policy" was sufficient to satisfy the initial burden).

356. Tex. Dept. of Cmty. Affairs v. Burdine, 450 U.S. 248, 253 (1981). 
policy is, in fact, a business necessity. ${ }^{357}$ If the defendant establishes a business necessity, the plaintiff must then show that the business necessity could be achieved with a less discriminatory business policy. ${ }^{358}$

Employees may premise disparate impact claims on adverse actions taken by employers against bilingual employees for violating a workplace English-only policy. Employers, however, typically refrain from imposing tangible or quantitative punishments on employees for violations of English-only policies. ${ }^{359}$ Thus, employees often cannot point to specific adverse actions taken under the policy-like firings or demotions - and therefore claim that workplace English-only policies violate Title VII by adversely affecting the "terms, conditions, or privileges of employment" or by creating a hostile work environment. Perhaps realizing that English-only plaintiffs often lack objective evidence of discrimination, the Equal Employment Opportunity Commission (EEOC) issued a series of guidelines addressing the legality of workplace English-only policies. ${ }^{360}$ The following subsections discuss: (1) the EEOC guidelines on workplace English-only policies, (2) the general rejection of the EEOC's guideline-based presumption by courts, (3) the consensus that English-only rules violate Title VII when applied to monolingual non-English speaking plaintiffs, and (4) the tendency of courts to dismiss generalized claims that English-only policies burden the "terms, conditions, or privileges" of non-English speaking employees' employment in violation of Title VII.

\section{a. EEOC Guidelines on Workplace English-Only Policies}

The Civil Rights Act of 1964 created the EEOC to eliminate discrimination in the workplace. $^{361}$ Congress gave the EEOC the authority to issue, amend, and rescind guidelines to carry out the provisions of Title VII. ${ }^{362}$ Concerned about potential abuse of Englishonly policies by employers, the EEOC established guidelines governing

357. Griggs v. Duke Power Co., 401 U.S. 424, 431-32 (1971); Melissa Meitus, English-Only Policies in the Workplace: Disparate Impact Compared to the EEOC Guidelines, 84 DENV. U. L. REV. 901, 905 (2007).

358. McCalips, supra note 342 , at 419 .

359. Perhaps the lack of quantitative punishments for violations of English-only policies is itself evidence that the English-only policy is not justified by business necessity. See generally Maldonado, 433 F.3d at 1306.

360. Garcia v. Spun Steak Co., 998 F.2d 1480, 1489 (9th Cir. 1993); see also EEOC Directives Transmittal, No. 915.003 (Dec. 2, 2002), available at http://www.eeoc.gov/policy/docs/nationalorigin.html\#VB1.

361. 42 U.S.C. § 2000e-4(a) (2000).

362. Id. $\S 2000 \mathrm{e}-12$ (a). 
English-only policies in the workplace. ${ }^{363}$ According to these guidelines, English-only policies that require "employees to speak only English at all times in the workplace [constitute] a burdensome term and condition of employment" which by prohibiting employees from speaking their primary language "disadvantages an individual's employment opportunities on the basis of national origin." ${ }^{364}$ The EEOC therefore concluded that blanket English-only policies are presumed to violate Title VII-thereby establishing plaintiff's prima facie case-because such policies "create an atmosphere of inferiority, isolation and intimidation based on national origin." 365

The EEOC took a more moderate position on English-only policies that apply only during specified times. Rather than applying a presumption of a Title VII violation, EEOC guidelines state that employers may use limited English-only policies if they are "justified by business necessity." 366 While the EEOC does not consider limited English-only policies inherently violative of Title VII, the EEOC does presume that the mere existence of a blanket or limited English-only policy will establish the plaintiff's prima facie case. ${ }^{367}$ The EEOC considers it evidence of discrimination if an employer fails to give notice to its employees of an English-only policy but nevertheless takes adverse employment action against an individual for violating the policy. ${ }^{368}$ Despite the outright rejection of these guidelines by some courts, ${ }^{369}$ the EEOC considers claims of discrimination involving language issues an enforcement priority. ${ }^{370}$ In 2007, the EEOC received 190 charges of national origin discrimination based on workplace English-only policies and sued based on two such charges. ${ }^{371}$ Consequently, both employees and employers should be aware that the EEOC guidelines play an

\footnotetext{
363. See EEOC Directives Transmittal, supra note 360.

364. 29 C.F.R. § 1606.7(a) (2008).

365. Id.; see also Spun Steak, 998 F.2d at 1489 ("The EEOC Guidelines provide that an employee meets the prima facie case in a disparate impact cause of action merely by proving the existence of the English-only policy.”); Long v. First Union Corp., 894 F. Supp. 933, 940 (E.D. Va. 1995) (same).

366. 29 C.F.R. $\$ 1606.7(\mathrm{~b})$

367. LEWIS \& NORMAN, supra note 328, at 81 ("Even if the rule is limited to certain times, the EEOC guideline ... gives it the same prima facie effect ....").

368. 29 C.F.R. $\$ 1606.7$ (c).

369. See, e.g., Spun Steak, 998 F.2d at 1489.

370. See Press Release, EEOC, Court Speaks: English Only Rule Unlawful; Awards EEOC $\$ 700,000$ for Hispanic Workers (Sept. 19, 2000), available at http://www.eeoc.gov/press/9-1900.html.

371. EEOC Settles Salvation Army Suit That Challenged English-Only Rules, 217 Daily Lab. Rep. (BNA) A-1 (Nov. 17, 2008).
} 
important role in defining their respective rights and liabilities with regard to workplace English-only policies. ${ }^{372}$

\section{b. Courts Generally Disregard the EEOC's Presumption of a Disparate Impact}

Courts generally agree that plaintiffs may not establish a prima facie disparate impact claim by merely proving the existence of a workplace English-only policy. Instead, courts typically require plaintiffs to prove the adverse impact of a workplace English-only policy. ${ }^{373}$ The EEOC guidelines, however, suggest that an employee may establish a prima facie disparate impact claim by merely proving the existence of a workplace English-only policy. ${ }^{374}$ According to the EEOC guidelines, a defendant employer must always prove that its English-only policy is supported by business necessity. ${ }^{375}$ Noting that the EEOC guidelines contravene Supreme Court precedent - not to mention the language of 42 U.S.C. $\S 2000 \mathrm{e}-2(\mathrm{k})$ - the Ninth Circuit expressly rejected the EEOC guidelines. ${ }^{376}$

Most courts agree with the Ninth Circuit and reject the EEOC's presumption that the mere existence of an English-only policy will establish a prima facie disparate impact claim. ${ }^{377}$ These courts reason that presuming a prima facie disparate impact-pursuant to the EEOC guidelines-contravenes the burden-shifting framework established by

372. Although courts have disagreed on whether to defer to the EEOC guidelines, Congress specifically discussed the EEOC English-only guidelines in 1991 when it considered other amendments to Title VII and ultimately decided to leave the EEOC guidelines intact. EEOC v. Premier Operator Servs., Inc., 113 F. Supp. 2d 1066, 1074 (N.D. Tex. 2000).

373. See Spun Steak, 998 F.2d at 1489 (rejecting the EEOC guidelines); Kania v. Archdiocese of Phila., 14 F. Supp. 2d 730, 735-36 (E.D. Pa. 1998) (same); Tran v. Standard Motor Prods., Inc., 10 F. Supp. 2d 1199, 1211 (D. Kan. 1998) (rejecting, without discussion, the EEOC's presumption); Long v. First Union Corp., 894 F. Supp. 933, 940 (E.D. Va. 1995) (rejecting the EEOC's presumption); EEOC v. Beauty Enters., Inc., No. 3:01CV378 (AHN), 2005 WL 2764822, at*11 (D. Conn. Oct. 25, 2005) (same); see also LewIS \& NoRmAN, supra note 328, at 82 ("The Ninth Circuit ... insisted that adverse impact must be proved and not merely presumed."). But cf. EEOC v. Synchro-Start Prods., Inc., 29 F. Supp. 2d 911, 915 (N.D. Ill. 1999) (following the EEOC's English-only regulatory framework).

374. Spun Steak, 998 F.2d at 1489 (stating that the "EEOC Guidelines provide that an employee meets the prima facie case in a disparate impact cause of action merely by proving the existence of the English-only policy"); Long, 894 F. Supp. at 940 (same).

375. Spun Steak, 998 F.2d at 1489.

376. Id. at $1489-90$.

377. See, e.g., Tran, 10 F. Supp. 2d at 1211 (rejecting, without discussion, the EEOC's presumption that the mere existence of a workplace English-only policy establishes a prima facie disparate impact claim); Beauty Enters., 2005 WL 2764822, at *11-12 (rejecting EEOC presumption). But cf. Synchro-Start Prods., 29 F. Supp. 2d at 915 (following the EEOC's Englishonly regulatory framework). 
the Supreme Court and codified by 42 U.S.C. $§ 2000 \mathrm{e}-2(\mathrm{k}){ }^{378}$ Although the Tenth Circuit refused to address the validity of the EEOC's presumption, its analysis suggests that a plaintiff must present some evidence of an adverse impact - besides the mere existence of an English-only policy - to establish a prima facie disparate impact claim. ${ }^{379}$ A prima facie disparate impact claim typically requires the plaintiff to prove both (1) a significant, adverse impact on the terms, conditions, or privileges of employment of a protected class and (2) "that the employee population in general is not affected by the policy to the same degree.", 380 Therefore, except in exceptional circumstances - such as when the plaintiff cannot speak any English or the policy is overly-broad-a plaintiff cannot establish a prima facie disparate impact claim by merely proving the existence of a workplace English-only policy.

c. Workplace English-Only Policies Have a Disparate Impact on NonEnglish Speaking Employees in Violation of Title VII

Although circuits disagree on whether English-only policies have significant adverse effects on bilingual plaintiffs, courts and the EEOC agree that a workplace English-only policy imposed against a monolingual, non-English speaking employee violates Title VII. ${ }^{381}$ These courts reason that an English-only policy applied against a monolingual, non-English speaking employee prevents the employee from communicating, and thus, the English-only policy may have an adverse impact in violation of Title VII. ${ }^{382}$ As discussed, pre-hiring English proficiency or competency requirements are generally permissible if necessary for effective job performance. Pre-hiring English proficiency requirements are therefore less likely to result in a Title VII discrimination complaint. Consequently, employers should consider language proficiency qualifications before hiring an employee because the adoption of a post-hiring English-only policy-as applied to monolingual non-English speaking employees - could be construed as disparate impact discrimination.

378. See, e.g., Beauty Enters., 2005 WL 2764822, at *9.

379. See Maldonado v. City of Altus, 433 F.3d 1294, 1304-06 (10th Cir. 2006).

380. Beauty Enters., 2005 WL 2764822, at *11 (citing Spun Steak, 998 F.2d at 1486).

381. See Spun Steak, 998 F.2d at 1488; Garcia v. Gloor, 618 F.2d 264, 270 (5th Cir. 1980); Synchro-Start Prods., 29 F. Supp. 2d at 915; 29 C.F.R. § 1606.7(a) (2008).

382. See Spun Steak, 998 F.2d at 1488; Gloor, 618 F.2d at 270. 
d. Discrimination in the Terms, Conditions, and Privileges of Employment

Courts typically reject the claim that workplace English-only policies have a significant, adverse impact on the "terms, conditions, or privileges of employment" of employees of non-English speaking national origins. The Fifth Circuit first addressed whether an employer's English-only policy constituted a discriminatory condition of employment. ${ }^{383}$ It held that Title VII neither confers substantive privileges nor forbids policies that employees can observe as a matter of choice, and therefore, the defendant employer did not violate Title VII by denying the plaintiff the privilege to speak his preferred language. ${ }^{384}$ In Garcia v. Spun Steak Co., the plaintiff similarly argued before the Ninth Circuit that the employer's English-only policy had an unlawful disparate impact on the terms, conditions, and privileges of employment because it denied Hispanic employees (1) the right to cultural expression and (2) the right to speak in their preferred language-Spanish. ${ }^{385}$ The Ninth Circuit rejected the plaintiffs' first argument, concluding that because Title VII does not confer substantive privileges - such as the right to self-expression-the employer did not violate Title VII. ${ }^{386}$ The Ninth Circuit also rejected the plaintiffs' second argument, reasoning that although the English-only policy disproportionately impacted Hispanic employees by preventing them from speaking their native language, this impact did not constitute a significant denial of an employment privilege given the ability of bilingual Hispanic employees to speak English. ${ }^{3}$

The holdings of the Fifth and Ninth Circuits are representative of the holdings of district court cases in which plaintiffs allege that Englishonly policies have a disparate impact on the terms, conditions, or privileges of their employment in violation of Title VII. ${ }^{388}$ Only a small minority of courts heed the EEOC guidelines. ${ }^{389}$ Accordingly, employee claims that English-only policies adversely affect the terms, conditions, and privileges of employment are not often successful because the

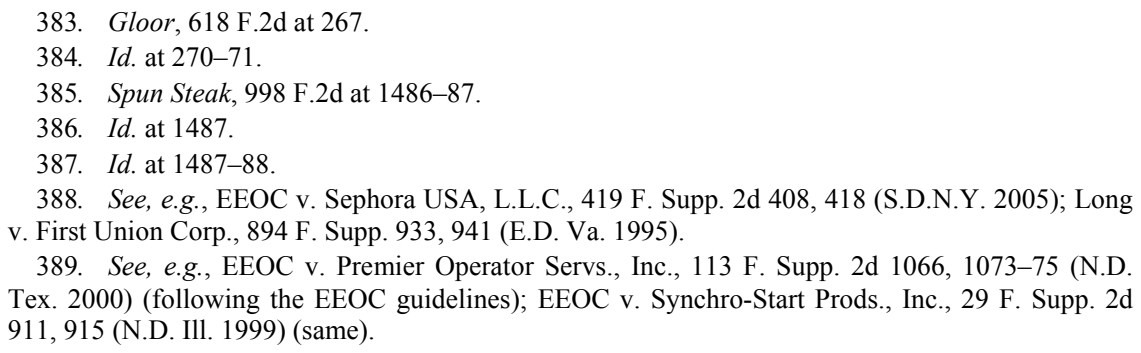


adverse effects are typically not sufficiently severe to establish the plaintiff's prima facie case. Nevertheless, a workplace policy that significantly burdens an employee's terms, conditions, or privileges of employment — such as a policy that creates a hostile work environmentwill likely violate Title VII.

\section{Hostile Work Environment Claims Predicated on Workplace English-Only Policies}

Recent Tenth Circuit caselaw suggests that workplace English-only rules may create a hostile work environment for bilingual employees of non-English speaking national origins. Title VII prohibits national origin discrimination that adversely affects the terms, conditions, or privileges of employment. ${ }^{390}$ Discrimination against an individual with respect to the terms and conditions of employment "is not limited to 'economic' or 'tangible' discrimination,... it covers more than 'terms' and "conditions' in the narrow contractual sense."391 A work environment is deemed hostile and in violation of Title VII where it is "sufficiently severe or pervasive to alter the conditions of the victim's employment and create an abusive working environment." $" 392$ To establish a prima facie hostile work environment claim, a plaintiff must prove that his or her workplace was, under the totality of the circumstances, objectively and subjectively hostile to members of the protected class. ${ }^{393}$

Courts and scholars disagree whether plaintiffs may predicate a hostile work environment claim on disparate impact theory. ${ }^{394}$ Plaintiffs generally predicate hostile work environment claims on intentional discrimination, and thus, hostile work environment claims generally proceed under disparate treatment theory. ${ }^{395}$ Recent challenges to workplace English-only policies, however, suggest that a plaintiff may predicate a hostile work environment claim - in the context of a workplace English-only policy — on either disparate treatment theory or disparate impact theory. ${ }^{396}$ Hostile work environment claims under

390. 42 U.S.C. $§ 2000 \mathrm{e}-2$ (a) (2000).

391. Nat'1 R.R. Passenger Corp. v. Morgan, 536 U.S. 101, 115-16 (2002) (citations omitted).

392. Harris v. Forklift Sys., Inc., 510 U.S. 17, 21 (1993).

393. Faragher v. City of Boca Raton, 524 U.S. 775, 787-88 (1998).

394. See L. Camille Hébert, The Disparate Impact of Sexual Harassment: Does Motive Matter?, 53 U. KAN. L. REV. 341, 357-58 (2005) ("[C]ourts have suggested from time to time that hostile work environment claims are akin to claims of disparate impact, asserting it is the effect on the victim, not the defendant's motivation, that gives rise to a claim.").

395. Maldonado v. City of Altus, 433 F.3d 1294, 1304 (10th Cir. 2006).

396. Id.; Montes v. Vail Clinic, Inc., 497 F.3d 1160, 1168 (10th Cir. 2007). 
disparate treatment theory require proof that the English-only policy was motivated by discriminatory intent. ${ }^{397}$ Hostile work environment claims under disparate impact theory, in contrast, require proof that the Englishonly policy disproportionately impacted individuals of non-Englishspeaking national origins. ${ }^{398}$ Although disparate impact theory and disparate treatment theory employ different burden-shifting frameworks, recent caselaw suggests that the success or failure of hostile work environment claims under either theory hinges on two related issues. ${ }^{399}$ The first issue is whether the plaintiff can establish — as part of her prima facie case - an objectively hostile work environment. ${ }^{400}$ The second issue is whether the English-only policy is narrowly-tailored to business necessities. ${ }^{401}$ The following discussion highlights the significance of these interrelated issues to hostile work environment claims.

Courts generally agree that a plaintiff must present some evidence beyond the mere existence of a narrowly-tailored English-only policy to establish a prima facie hostile work environment. ${ }^{402}$ Bilingual plaintiffs often argue that English-only policies contribute to a hostile work environment because bilingual employees must work in constant fear that a slip of the tongue could expose them to sanctions. The Fifth Circuit, in Garcia v. Gloor, held that a workplace English-only policy cannot have a disparate impact on bilingual employees because, for them, compliance with an English-only policy is a matter of choice-a matter of exercising a mutable characteristic. ${ }^{403}$ Recent psycho-linguistic studies, however, suggest that language use is not solely a matter of preference, but rather, that bilingual individuals unconsciously revertbecause of a phenomenon known as "code switching"- to speaking in their native tongue. ${ }^{404}$ Code switching makes compliance with workplace English-only policies more difficult for bilingual employees

397. Montes, 497 F.3d at 1170 n.15; Maldonado, 433 F.3d at 1307-08.

398. See Maldonado, 433 F.3d at 1303-04 (“[A] disparate-impact claim does not require a showing of discriminatory intent.").

399. See, e.g., id. at 1304 ("The allocation of the burdens of proof in disparate-impact cases ... is more rigorous than in a disparate treatment case because a plaintiff must not merely show circumstances raising an inference of discriminatory impact but must demonstrate the discriminatory impact at issue."); see also EEOC v. Synchro-Start Prods., Inc., 29 F. Supp. 2d 911, 912 (N.D. Ill. 1999).

400. See, e.g., Maldonado, 433 F.3d at 1304-06.

401. See, e.g., id. at 1306-07.

402. Compare Synchro-Start Prods., 29 F. Supp. 2d at 912-15 (deferring to the EEOC guidelines), with Garcia v. Spun Steak Co., 998 F.2d 1480, 1489-90 (9th Cir. 1993) (rejecting the EEOC guidelines).

403. Garcia v. Gloor, 618 F.2d 264, 270 (5th Cir. 1980); see also Colón, supra note 339, at 23839.

404. McCalips, supra note 342 , at 431 . 
than for monolingual employees, and thus, bilingual employees - who often share a particular non-English speaking national origin-run a greater risk of discipline for violating the policy. ${ }^{405}$ These studies undermine the Fifth Circuit's analysis and support recent court decisions acknowledging the difficulty bilingual employees have complying with workplace English-only policies. ${ }^{406}$

Nevertheless, the mere existence of an English-only policy, standing alone, does not establish a prima facie hostile work environment claim. ${ }^{407}$ The Tenth Circuit held, in Maldonado v. City of Altus, that the plaintiff raised a genuine issue of material fact as to whether the employer's English-only policy created a hostile work environment for Hispanic employees. ${ }^{408}$ The Tenth Circuit reasoned that the EEOC guidelines, combined with other evidence of discrimination, suggest that reasonable jurors could conclude that the employer's blanket English-only policy created a prima facie hostile work environment. ${ }^{409}$ The hostility of a work environment is determined under the totality of the circumstances. $^{410}$ Thus, courts consider the circumstances surrounding the enactment of the English-only policy, the effects of the policy, the justifications for the policy, and the scope of the policy to determine whether the policy creates a hostile work environment. ${ }^{411}$ A plaintiff may support a prima facie hostile work environment claim with evidence that the employer lacked business reasons for the policy, ${ }^{412}$ that the policy was over-inclusive, ${ }^{413}$ that ethnic taunting accompanied the policy, ${ }^{414}$ or that bilingual employees reasonably feared discipline for inadvertently violating the policy. ${ }^{415}$

Following its decision in Maldonado, the Tenth Circuit again considered, in Montes v. Vail Clinic, Inc., whether a workplace Englishonly policy created a hostile work environment. ${ }^{416}$ In Montes, the defendant hospital adopted an English-only policy that applied to all

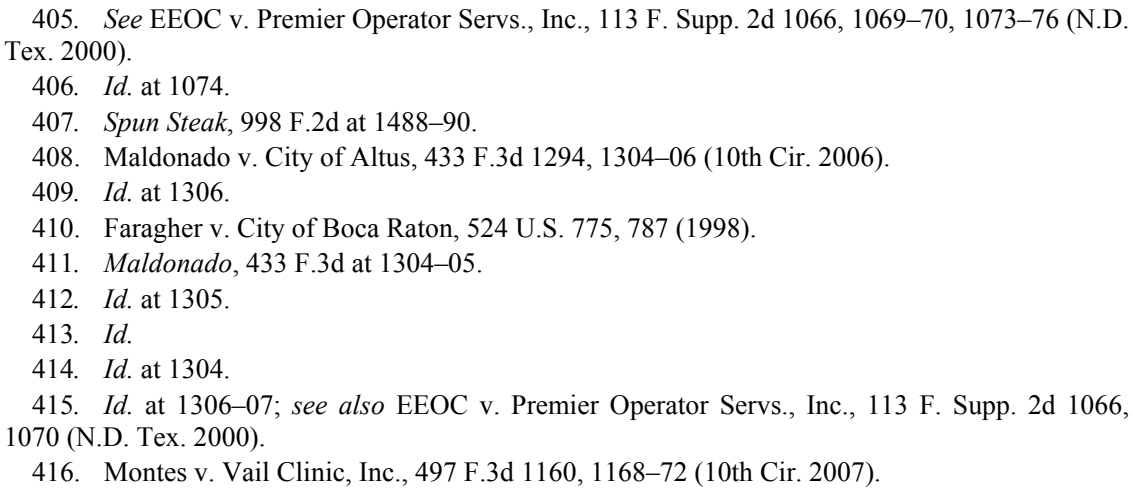


communications in the hospital's operating room department. ${ }^{417}$ Several Hispanic housekeepers sued the hospital alleging the policy intentionally created a hostile work environment. ${ }^{418}$ The Tenth Circuit held that the plaintiff failed to demonstrate an objectively hostile work environment because the English-only policy did not apply outside the operating room department and was consistent with business necessities. ${ }^{419}$ Taken together, Maldonado and Montes suggest that the existence of a prima facie hostile work environment hinges, in part, on the business reasons for the English-only policy. ${ }^{420}$ Thus, as a practical matter, a hostile work environment claim will generally fail under both disparate treatment theory and disparate impact theory if the workplace English-only policy is narrowly-tailored to, consistent with, and motivated by business necessities.

Recent court decisions generally acknowledge-like the EEOC guidelines - that overly-broad English-only policies may create a hostile work environment. $^{421}$ At the same time, court decisions also reflect a tendency to allow employers to utilize narrowly-tailored English-only policies consistent with legitimate business necessities. ${ }^{422}$ Though no circuit has (and few courts have) expressly adopted the EEOC's presumption, some courts accept the EEOC guidelines as evidence that reasonable jurors may find that workplace English-only policies create a hostile work environment. ${ }^{423}$ In sum, recent cases suggest a plaintiff cannot establish a prima facie hostile work environment claim by merely presenting evidence of a limited English-only policy. Rather, plaintiffs may establish a prima facie hostile work environment case by presenting objective evidence that the English-only policy had significant, adverse

\footnotetext{
417. Id. at 1171.

418. Id. at $1170 \mathrm{n} .15$.

419. Id. at $1171-72$.

420. Id.; Maldonado, 433 F.3d at 1304 (stating that the lack of an apparent justification for a workplace English-only policy makes an inference of a prima facie hostile work environment reasonable).

421. See, e.g., Montes, 497 F.3d at 1170 n.15; Maldonado, 433 F.3d at 1304; EEOC v. Premier Operator Servs., Inc., 113 F. Supp. 2d 1066, 1076 (N.D. Tex. 2000); EEOC v. Synchro-Start Prods., Inc., 29 F. Supp. 2d 911 (N.D. Ill. 1999).

422. See, e.g., Montes, 497 F.3d at 1171-72 (holding that limited English-only rule did not create a hostile work environment, in part, because the policy was justified by business necessity); Barber v. Lovelace Sandia Health Sys., 409 F. Supp. 2d 1313, 1316 (D.N.M. 2005) (affirming summary judgment for employer on employees' English-only disparate impact claim, in part, because the employer proffered a legitimate business reason for the policy); Long v. First Union Corp., 894 F. Supp. 933, 941 (E.D. Va. 1995) (rejecting plaintiff's disparate impact English-only claim because the policy was justified by business necessity).

423. Maldonado, 433 F.3d at 1306 .
} 
effects on employees of non-English speaking national origins, which may include consideration of the business reasons for the policy.

\section{Section 1981: Intentional Discrimination}

Claims that English-only policies are intentionally discriminatory in violation of $\S 1981$ typically fail for the same reasons as analogous Title VII disparate treatment claims. Section 1981 prohibits both public and private employers from using English-only policies as a pretext for racial discrimination. ${ }^{424}$ Under $§ 1981$ :

All persons within the jurisdiction of the United States shall have the same right in every State and Territory to make and enforce contracts, to sue, be parties, give evidence, and to the full and equal benefit of all laws and proceedings for the security of persons and property as is enjoyed by white citizens, and shall be subject to like punishment, pains, penalties, taxes, licenses, and exactions of every kind, and to no other.

Though § 1981 does not protect employees from language discrimination, ${ }^{426}$ it does protect employees from intentional racial discrimination. ${ }^{427}$ Because $\S 1981$ protects individuals from intentional racial discrimination, it necessarily prohibits employers from using English-only policies as a pretext for racial discrimination. ${ }^{428}$ The same burden-shifting framework that applies to Title VII disparate treatment claims applies to $\S 1981$ claims - the McDonnell Douglas framework. ${ }^{429}$ To establish a prima facie case under $\S 1981$, a plaintiff must prove intentional discrimination through direct or circumstantial evidence. ${ }^{430}$ Evidence of discriminatory intent may be inferred from the disparate impact English-only policies have on racial minorities ${ }^{431}$ as well as a

424. 42 U.S.C. § 1982(c) (2000); see also Gen. Bldg. Contractors Ass'n, Inc. v. Pennsylvania, 458 U.S. 375, 388 (1982); Runyon v. McCrary, 427 U.S. 160, 169 (1976) (holding that $§ 1981$ also applies to purely private conduct).

425. 42 U.S.C. § 1981(a).

426. Id.

427. CBOCS W., Inc. v. Humphries, 128 S. Ct. 1951, 1957 (2008) (quoting S. REP. No. 101315 , at $6(1990))$.

428. See Saint Francis Coll. v. Al-Khazraji, 481 U.S. 604, 613 (1987) ("Congress intended to protect from discrimination identifiable classes of persons who are subjected to intentional discrimination solely because of their ancestry or ethnic characteristics.").

429. Maldonado v. City of Altus, 433 F.3d 1294, 1308 (10th Cir. 2006).

430. Gen. Bldg. Contractors Ass'n, Inc. v. Pennsylvania, 458 U.S. 375, 391 (1982); see also BARBARA LiNDEMANN \& PAUl GROSSMAN, 1 EMPLOYMENT DisCRiMinATION LAW Ch. 11, 365-67 (3d ed. 1996).

431. Maldonado, 433 F.3d at 1308 . 
history of departures from procedural norms, but the disparate impact must be strong, and the correlation precise, to establish the plaintiff's prima facie case. ${ }^{432}$ If the plaintiff satisfies his or her initial burden, the burden shifts to the employer to show that it had a legitimate nondiscriminatory reason for the policy. ${ }^{433}$ If the employer satisfies its burden, the plaintiff may then prove that the reason offered by the employer was merely a pretext for unlawful discrimination. ${ }^{434}$

Unlike a Title VII disparate treatment claim, ${ }^{435}$ a plaintiff need not satisfy the more detailed procedural requirements of Title VII before bringing a claim under $\S 1981 .{ }^{436}$ Section 1981 therefore has practical advantages over Title VII in that (1) it applies to employers with less than fifteen employees, ${ }^{437}$ (2) it allows prevailing plaintiffs to recover compensatory and punitive damages without the caps applied to similar Title VII damages; ${ }^{438}$ (3) it has a longer, four-year statute of limitations; ${ }^{439}$ (4) it has no exhaustion of administrative remedies requirement, ${ }^{440}$ and (5) it allows for individual liability, unlike Title VII. ${ }^{441}$ Section 1981 thus provides some plaintiffs with a viable cause of action for intentional discrimination that may not be available under Title VII. ${ }^{442}$ Nevertheless, to recover under $\S 1981$, the plaintiff must still prove that the challenged English-only policy was merely a pretext for intentional race-based discrimination, and thus, most English-only plaintiffs will fare the same under $§ 1981$ as under Title VII.

\footnotetext{
432. Vill. of Arlington Heights v. Metro. Hous. Dev. Corp., 429 U.S. 252, 264-68 (1977).

433. McDonnell Douglas Corp. v. Green, 411 U.S. 792, 802 (1973).

434. Id. at 804 .

435. Maldonado, 433 F.3d at 1307; Jurado v. Eleven-Fifty Corp., 813 F.2d 1406, 1412 (9th Cir. 1987); Lowe v. City of Monrovia, 775 F.2d 998, 1010 (9th Cir. 1985).

436. CBOCS W., Inc. v. Humphries, 128 S. Ct. 1951, 1959 (2008).

437. Compare Rivers v. Roadway Express, Inc., 511 U.S. 298, 304 n.3 (1994) ("Even in the employment context, § 1981's coverage is broader than Title VII's, for Title VII applies only to employers with 15 or more employees, see 42 U.S.C. $\S 2000 \mathrm{e}(\mathrm{b})$, whereas $\S 1981$ has no such limitation."), and Johnson v. Ry. Express Agency, Inc., 421 U.S. 454, 460-61 (1975) ("Section 1981 is not coextensive in its coverage with Title VII. The latter is made inapplicable to certain employers. 42 U.S.C. $\S 2000 \mathrm{e}(\mathrm{b}) . ”)$, with 42 U.S.C. $\S 2000 \mathrm{e}(\mathrm{b})(2000)$.

438. 42 U.S.C. $\$ 1981$ (a) (2000).

439. Section 1981 has a four year statute of limitations. 28 U.S.C. $\S 1658$ (a) (2000); Jones v. R.R. Donnelley \& Sons Co., 541 U.S. 369, 380 (2004). Title VII, in contrast, requires formal charges within 180 days of the unlawful employment practice. 42 U.S.C. $\S 2000 \mathrm{e}-5(\mathrm{e})$.

440. Surrell v. Cal. Water Serv. Co., 518 F.3d 1097, 1103 (9th Cir. 2008).

441. Compare Jett v. Dallas Indep. Sch. Dist., 491 U.S. 701, 733 (1989) (permitting individual liability under $\S 1981$ ), with Lissau v. S. Food Serv., Inc., 159 F.3d 177, 180 (4th Cir. 1998) (denying individual liability under Title VII), and Haynes v. Williams, 88 F.3d 898, 899 (10th Cir. 1996) (same).

442. Donaldson v. Taylor Prods. Div. of Tecumseh Prods. Co., 620 F.2d 155, 158 (7th Cir.
} 1980). 


\section{E. Title VII and § 1981: Retaliation}

The Supreme Court has recently opened the possibility that employers could be sued for retaliating against employees who complain about discrimination under $\S 1981,{ }^{443}$ even if the court ultimately concludes that no unlawful discrimination occurred. ${ }^{444}$ As discussed in section IV, plaintiffs need not exhaust their administrative remedies under Title VII to bring a $\S 1981$ claim. $^{445}$ Thus, plaintiffs like those in Maldonado who failed to include retaliation charges in their EEOC complaint would not, for that reason, be barred from bringing a retaliation suit under $\S 1981 .{ }^{446}$ Accordingly, employers may be subject to liability for retaliation regardless of whether an employee exhausts his or her administrative remedies.

The Supreme Court has also opened the possibility that employers could be sued for retaliating against an individual who helped another employee assert his or her $\S 1981$ rights. ${ }^{447}$ Section 1981 prohibits employers from taking retaliatory action against any employee because the employee helped another employee secure his or her $\S 1981$ rights. $^{448}$ This prohibition against retaliation applies even if the underlying $§ 1981$ charge lacks merit. ${ }^{449}$ Accordingly, employers may not take adverse action against any employee, regardless of his or her national origin, who assists other employees in challenging the employer's English-only policy. For instance, $\S 1981$ prohibits an employer from retaliating against a white employee who tells his Hispanic co-workers that he believes that their employer's English-only policy violates the Hispanic co-worker's $\S 1981$ rights. Employers should be aware that $\S 1981$ 's prohibition on retaliation extends not only to employees who directly challenge allegedly discriminatory employment practices, but also to third parties who help other employees assert their $\S 1981$ rights.

\footnotetext{
443. CBOCS W., Inc. v. Humphries, 128 S. Ct. 1951, 1954-55 (2008).

444. McClain v. N.W. Cmty. Corr. Ctr. Judicial Corr. Bd., 440 F.3d 320, 336 (6th Cir. 2006).

445. CBOCS W., Inc., 128 S. Ct. at 1959; Donaldson, 620 F.2d at 158 .

446. Compare CBOCS W., 128 S. Ct. at 1959, with Maldonado v. City of Altus, 433 F.3d 1294, 1308 (10th Cir. 2006).

447. CBOCS W., 128 S. Ct. at $1958-59$.

448. Id. at 1955.

449. Aman v. Cort Furniture Rental Corp., 85 F.3d 1074 (3d Cir. 1996); Sumner v. U.S. Postal Serv., 899 F.2d 203, 209 (2d Cir. 1990).
} 


\section{F. Section 1983 Actions for Denial of First Amendment Rights}

\section{Background}

Section 1983 provides employees with a private cause of action against state and local government employers who enact English-only policies that violate federally protected rights. ${ }^{450}$ State employers who restrict the use of language in the workplace may be faced with employee lawsuits alleging that such policies violate employee First Amendment rights. ${ }^{451}$ The First Amendment to the U.S. Constitution states that "Congress shall make no law ... abridging the freedom of speech." Although literally applicable only to Congress, the First Amendment also prohibits - via the Due Process Clause of the Fourteenth Amendmentother government entities from denying individuals their right to freedom of speech. ${ }^{453}$ State and local employers thus fall within the ambit of the First Amendment and may restrict the speech of employees only if the restriction satisfies the requirements established by the Supreme Court in a line of cases beginning with Pickering v. Board of Education. ${ }^{454}$

The Pickering line of cases spawned two different tests to determine if a public workplace speech restriction violates the First Amendmentan ex ante test and an ex post test. The ex post test-first articulated in Pickering and later expanded by Mt. Healthy City School District Board of Education v. Doyle $e^{455}$ - applies when the government takes an adverse employment action against an employee for specific speech after the speech took place. ${ }^{456}$ The ex ante test, in contrast, was first applied in United States v. National Treasury Employee's Union (NTEU) ${ }^{457}$ and applies to speech restrictions that prohibit government employee speech before the speech actually occurs. ${ }^{458}$ Public workplace speech restrictions that fail to satisfy either the Mt. Healthy test or the NTEU test violate the First Amendment. ${ }^{459}$

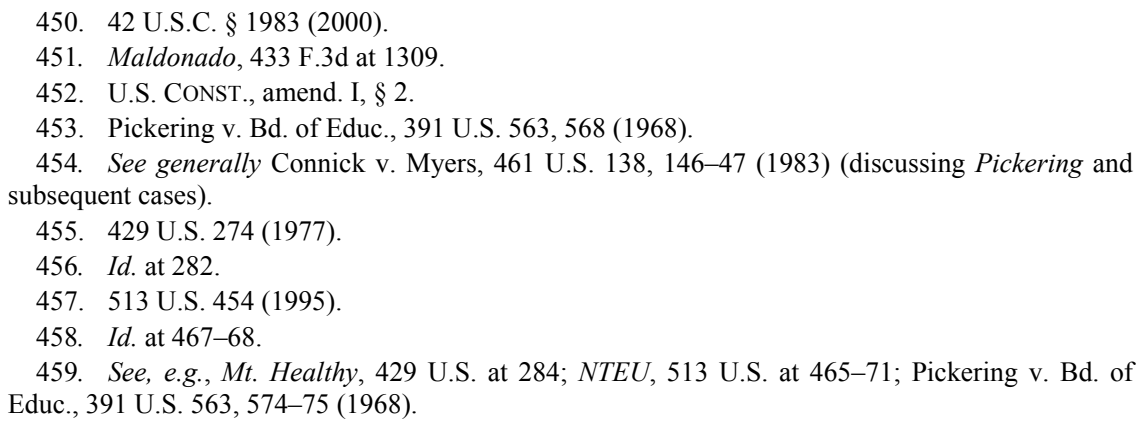


Under the Mt. Healthy test, a court first considers whether the public employee's speech touches on a matter of public concern. ${ }^{460}$ If the speech touches upon a matter of public concern, the court then assesses whether the employer's challenged policy balances (1) the interests of the public employee in commenting on matters of public concern with (2) the interest of the employer "in promoting the efficiency of the public services it performs through its employees." ${ }^{~}$ If such a balance is achieved, the employee's claim may not proceed unless the employee establishes that the challenged policy was, in fact, motivated by the employee's exercise of his or her constitutional right. ${ }^{462}$ Even if the employee makes such a showing, the public employer may nevertheless defeat the employee's claim by showing that it would have made the same decision absent the employee's constitutionally-protected speech. $^{463}$

In contrast to the Mt. Healthy test, the NTEU test applies to ex ante speech restrictions-policies that restrict employee speech before it occurs. ${ }^{464}$ To sustain an ex ante speech restriction under the NTEU test, "[t]he government must show that the interests of both potential audiences and a vast group of present and future employees in a broad range of present and future expression are outweighed by that expression's 'necessary impact on the actual operation' of the Government." "465 The NTEU test applies only the first two factors of the Mt. Healthy test because "unlike an adverse action taken in response to actual speech, [an ex ante speech restriction] chills potential speech before it happens." 466 To account for the greater restriction on expression posed by an ex ante restriction, the NTEU test eliminates the employee's final burden, and the employer's final defense, under the $M t$. Healthy test.

Federal law allows state and local government employees to challenge English-only policies as violations of the First Amendment. ${ }^{467}$ Section 1983 grants a private cause of action to individuals who are subjected to a deprivation of their rights, privileges, or immunities secured by federal law or the Constitution of the United States by a

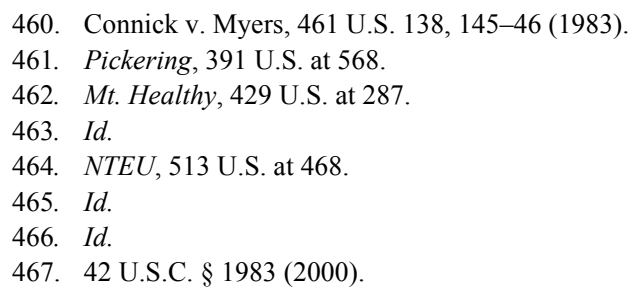


person acting under the color of state or local law. ${ }^{468}$ The Tenth Circuit was the first federal circuit court to consider whether a workplace English-only policy, enacted by a unit of state government, violates the First Amendment and is therefore actionable under $\S 1983 .{ }^{469}$ The following section discusses the Tenth Circuit's holding that a public workplace English-only policy does not violate the First Amendment, and then goes on to consider why courts may construe this holding narrowly.

2. The Tenth Circuit's Conclusion that Public Workplace English-Only Policies Do Not Violate the First Amendment

Despite a recent holding to the contrary, English-only policies in the public workplace that fail to balance employee and employer interests may well violate the First Amendment. In Maldonado v. City of Altus, the Tenth Circuit Court of Appeals considered a $\S 1983$ claim against the City of Altus in which Hispanic city employees argued that Altus's English-only policy violated their First Amendment rights. ${ }^{470}$ In 2002, the commissioner of Altus's Street Maintenance Department enacted an English-only policy for employees of the department in response to complaints from non-Spanish speaking employees. ${ }^{471}$ Following the enactment of the English-only policy, an employee wrote a letter to the city's director of human resources to complain about the policy and serve the city with a discrimination complaint in accordance with policy procedures. $^{472}$ Despite receiving the letter and the complaint, Altus's director of human resources extended the English-only policy to cover all city employees. ${ }^{473}$ The new city-wide English-only policy restricted work-time employee communications to English, but made an exception for situations where "necessary or prudent to communicate with a citizen ... in his or her native language due to the person or entity's limited English language skills." ${ }^{\text {474 }}$ The English-only policy also excepted private communications between co-workers while on break and private communications between an employee and a family

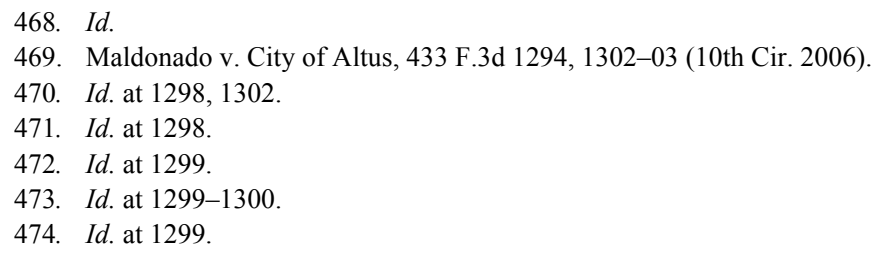


member, ${ }^{475}$ although some evidence suggested that the English-only policy extended beyond its written terms. ${ }^{476}$

Hispanic city employees subsequently filed suit against the city under $\S 1983$ alleging that the English-only policy denied Hispanic city employees their First Amendment rights. ${ }^{477}$ The district court granted summary judgment to the city on the employees' $\$ 1983$ claim. ${ }^{47}$ The Tenth Circuit affirmed, holding that the employees' § 1983 claim did not satisfy the first and third prongs of the Mt. Healthy test, and therefore, the employees' First Amendment rights were not violated. ${ }^{479}$ The Tenth Circuit reasoned that the English-only policy did not touch on a matter of public concern because the proscribed speech consisted of "mundane, quotidian conversation" unrelated to an expression of ethnic pride or an ongoing debate about race relations. ${ }^{480}$ The court further noted that had the plaintiffs intended to use the Spanish language to "emphasize a point or otherwise communicate a message on a matter of public concern, this would be a different case." 481 The Tenth Circuit similarly concluded that the plaintiffs failed to satisfy the third prong of the Mt. Healthy test because they did not show that the city intended to silence speech on matters of public concern by enacting the English-only policy. ${ }^{482}$

Judge Seymour responded to the Tenth Circuit's holding with a vigorous, well-reasoned dissent declaring that the city's English-only policy constituted an ex ante speech restriction that must be analyzed under the NTEU test-not under the Mt. Healthy test applied by the majority. ${ }^{483}$ Since delivering the opinion, the vast majority of commentators have agreed with the dissent, and few, if any, commentators have argued that the Tenth Circuit applied the correct First Amendment test in dismissing the Hispanic employees' $§ 1983$ claim. $^{484}$ Accordingly, state and local employers and employees should not rely on

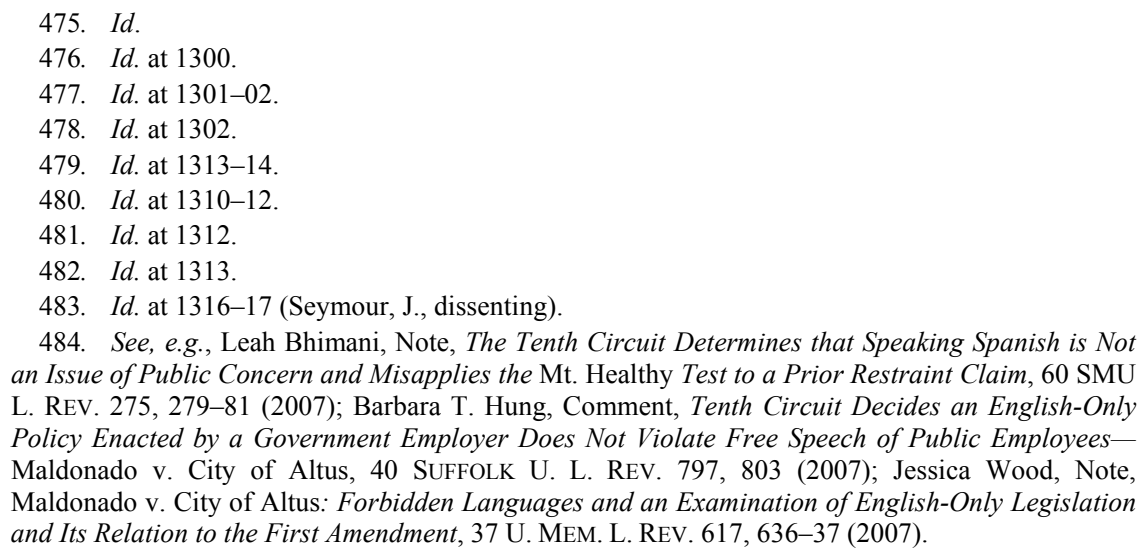
an Issue of Public Concern and Misapplies the Mt. Healthy Test to a Prior Restraint Claim, 60 SMU L. Rev. 275, 279-81 (2007); Barbara T. Hung, Comment, Tenth Circuit Decides an English-Only Policy Enacted by a Government Employer Does Not Violate Free Speech of Public EmployeesMaldonado v. City of Altus, 40 SUFFolK U. L. REV. 797, 803 (2007); Jessica Wood, Note, Maldonado v. City of Altus: Forbidden Languages and an Examination of English-Only Legislation and Its Relation to the First Amendment, 37 U. MEM. L. REV. 617, 636-37 (2007). 
the Tenth Circuit's decision in Maldonado to conclude that limited English-only policies will not violate the First Amendment rights of state or local employees because the test the Tenth Circuit used to reach its holding was likely incorrect.

The flaw in the Tenth Circuit's reasoning stems from its failure to recognize that the Mt. Healthy test should be applied only to retaliatory, ex post speech restrictions - never to ex ante speech restrictions. ${ }^{485}$ Instead, the court should have applied the NTEU test to the English-only policy because it constitutes an ex ante speech restriction. ${ }^{486}$ The NTEU test recognizes that applying the third and fourth prongs of the Mt. Healthy test to an ex ante speech restriction is illogical and contravenes the rule that ex ante speech restrictions, because of their chilling effect, are subject to heightened scrutiny. The Tenth Circuit implicitly recognized the error in its logic stating that "[h]ow to translate [the third prong of the Mt. Healthy test] to the context of an ex ante prohibition, as opposed to imposition of an ex post sanction, is not obvious." ${ }^{487}$ Nevertheless, the Tenth Circuit continued its analysis of the employees' claims under the Mt. Healthy test, concluding that the plaintiffs failed to show that the employer's English-only policy was motivated by an intent to silence protected speech. ${ }^{488}$ As commentators correctly point out, the circuit courts uniformly apply the Mt. Healthy test to retaliatory, ex post speech restrictions - not to ex ante restrictions. ${ }^{489}$ Recognizing this, the Tenth Circuit previously stated that retaliation is a precondition to the application of the Mt. Healthy test. ${ }^{490}$

Another matter limiting the precedential value of Maldonado is the Tenth Circuit's analysis of whether speaking Spanish at work constitutes a matter of public concern. The public concern is a particularly amorphous concept. ${ }^{491}$ The language used by public employees at work may well constitute a matter of public concern depending on how broadly or narrowly one frames the public concern. Outside the

\footnotetext{
485. Maldonado, 433 F.3d at 1316 (Seymour, J., dissenting); Bhimani, supra note 484, at 275.

486. Maldonado, 433 F.3d at 1317 (Seymour, J., dissenting).

487. Id. at 1313 (majority opinion)

488. Id. at 1313-14.

489. Bhimani, supra note 484 , at 280.

490. Belcher v. City of McAlester, 324 F.3d 1203, 1207 n.4 (10th Cir. 2003).

491. Counterintuitively, a government employee need not address his or her speech to the general public to speak on a matter of public concern. Connick v. Myers, 461 U.S. 138, 148-49 (1983). In fact, a public employee can speak on a matter of public concern although the employee never seeks to inform the public with his or her speech. Id. at 148 . Courts judge whether speech is a matter of public concern by its "content, form, [and] context." Id. at 147. Consequently, whether speech constitutes a matter of public concern requires a relatively unstructured case-by-case analysis.
} 
workplace, considerable disagreement exists as to whether foreign language use constitutes a matter of public concern. ${ }^{492}$ Several cases suggest that language choice implicates the public concern because of its cultural importance. ${ }^{493}$ The Tenth Circuit determined that the mere act of speaking Spanish was not a matter of public concern but conceded that communications of broader public importance-such as speech relevant to evaluating the conduct of government - may well constitute speech on a matter of public concern. ${ }^{494}$ Consequently, the context-specific NTEU/Mt. Healthy balancing test may well determine the constitutionality of other public workplace English-only policies.

In sum, the Tenth Circuit may have erred in applying the Mt. Healthy test to an ex ante speech restriction and in characterizing employee language use as a matter of private concern. If the Tenth Circuit did, in fact, err in applying the Mt. Healthy test to an ex ante speech restriction, then the more plaintiff-friendly NTEU test will likely apply. If the NTEU test applies to future challenges, the Tenth Circuit's public concern analysis in Maldonado remains relevant. Future judicial decisions, however, may well distinguish the public concern analysis in Maldonado if the proscribed non-English communications extend beyond "mundane, quotidian conversation" to issues of broader public importance-such as speech relevant to the evaluation of government or speech communicating ethnic pride. ${ }^{495}$ Public employers should therefore exercise caution in adopting English-only policies because such policies may run afoul of the First Amendment under the context-specific NTEU/Mt. Healthy balancing test. Ultimately, the precedential value of Maldonado is limited, and the constitutionality of public workplace English-only policies will likely turn on the facts of each case.

\section{Considerations for Public Employees and Employers}

The constitutionality of a public workplace English-only policy hinges on the answers to two questions. ${ }^{496}$ First, does the English-only policy restrict speech on a matter of public concern ${ }^{497}$ Second, does the

\footnotetext{
492. Today, thirty states have adopted "Official-English" statutes. See supra Part II.C. Perhaps adoption of these statutes suggests that workplace language use constitutes a matter of public concern.

493. Maldonado, 433 F.3d at 1319 (Seymour, J., dissenting) (citing Garcia v. Spun Steak Co., 998 F.2d 1480 (9th Cir. 1993); Hernandez v. New York, 500 U.S. 352 (1991)).

494. Id. at 1311-12.

495. Id. at 1312 .

496. Maldonado, 433 F.3d at 1318 (Seymour, J., dissenting).

497. Id.
} 
English-only policy balance the public employer's interest in running an effective and efficient workplace with the employee's interest in speaking Spanish $?^{498}$ Regardless of whether an English-only policy restricts speech on matters of public concern, an English-only policy that successfully balances the First Amendment rights of employees with the employer's interest in promoting an effective and efficient workplace will be deemed constitutional under the NTEU test. ${ }^{499}$ Accordingly, public employers should refrain from enacting English-only policies unless the policies are narrowly tailored and justified by legitimate business necessities; it is these types of policies that are more likely to balance the interests of employees and employers. Likewise, public employees should not accept overly-broad English-only policies which have no connection to running an effective and efficient workplace.

\section{G. Conclusion}

Ultimately, the legality of workplace English-only policies is highly context specific. To avoid costly litigation, employers should thoroughly consider the costs and benefits of enacting an English-only policy. As a general rule, employers should (1) adopt English-only policies only when supported by legitimate business necessities; (2) tailor English-only policies as narrowly as possible to legitimate business necessities; (3) thoroughly document the business necessities supporting the adoption of an English-only policy; (4) give employees notice of the policy; (5) give serious consideration to employee questions and concerns regarding the English-only policy; and (6) inform employees that isolated, accidental violations of the policy will not result in adverse employment action.

498. Id.

499. Pickering v. Bd. of Educ., 391 U.S. 563, 568 (1968). 